\title{
A REGULAMENTAÇÃO DA PUBLICIDADE INFANTIL: LIBERDADE DE EXPRESSÃO E PROTEÇÃO DA CRIANÇA E DO ADOLESCENTE
}

THE REGULATION OF CHILD ADVERTISING: FREEDOM OF EXPRESSION AND PROTECTION OF CHILDREN AND ADOLESCENTS

Guilherme Zocollaro Nogueira ${ }^{1}$

ISSUE DOI: $10.21207 / 1983.4225 .383$

\section{RESUMO}

O presente trabalho faz uma análise sobre a regulamentação da publicidade infantil no Brasil, tema presente nos debates jurídicos nos últimos anos e merecedor de atenção, vez que ganhou destaque no ano de 2014, ao ser publicada a Resolução 163 do Conanda, sigla para Conselho Nacional dos Direitos da Criança e do Adolescente, que acabou vetando qualquer espécie de publicidade voltada ao público infantil. A decisão gerou inúmeras reportagens, ações judiciais, alterações em programações infantis, dentre outras consequências. Desse modo é abordado, inicialmente, o conceito de liberdade de expressão, importante direito constitucional, e sua restrição, através de exemplos práticos existentes em nosso país; o qual se relaciona com a liberdade de publicidade, derivada desse amplo direito e prevista nos artigos $5^{\circ}$, IX e 220 da Magna Carta. Busca-se o confronto através da abordagem do conceito histórico de criança e ado-

\footnotetext{
1 Graduando em Direito pela Faculdade de Direito de Franca, cursando o último ano. Participou do Programa de Iniciação Científica da Faculdade de Direito de Franca (2013). Foi monitor de Direito Civil (2013). Monitor de Prática Jurídica I. Foi estagiário na Procuradoria Geral do Município de Franca/SP. Estagiário em escritório de advocacia.
} 
lescente, do qual se extrai a conhecida Teoria da Proteção Integral, presente em nossa Constituição Federal de 1988, responsável por instituir em nosso pátrio direito a prioridade, inclusive do Estado, na proteção desses indivíduos, fundamento legal utilizado pela resolução supracitada. Foi realizado um estudo sobre a atual regulamentação da publicidade no Brasil, com destaque para a adoção do sistema Misto, o qual conjuga um sistema autorregulamentar, instituído pelas próprias empresas de publicidade, e um sistema estatal. Utiliza-se, ao final, do Direito Comparado, através de breves comentários sobre o sistema adotado em alguns dos países mais importantes da atual sociedade, entre vantagens e desvantagens.

Palavras-chave: Publicidade infantil. Liberdade de expressão. Regulamentação da publicidade. Criança e adolescente.

\section{ABSTRACT}

This paper analyzes on the regulation of children's advertising in Brazil, this theme in the legal debates in recent years and worthy of attention, since it came to prominence in 2014, when it issued Resolution 163 of Conanda, which stands for National Council the Rights of Children and Adolescents, which ended up vetoing any kind of advertising aimed at children. The decision has generated numerous reports, lawsuits, changes in children's programs, among other consequences. Thus is approached initially the concept of freedom of expression, important constitutional right, and his stint through existing practical examples in our country; which relates to the freedom of advertising, derived from this broad right and laid down in Articles 5, IX and 220 of the Constitution. Seeks to confrontation through historical concept child approach and adolescents, which is extracted the well-known theory of Integral Protection, present in our 1988 Constitution, responsible for establishing in our right parental priority, including the state, in protecting these individuals, legal basis used by the aforementioned resolution. It conducted a study on the current regulation of advertising in Brazil, highlighting the adoption of the Joint system, which blends a private regulation system instituted by their own advertising companies, and state system. It is used at the end of Comparative Law, by brief comments on the system adopted in some of 
the most important countries of today's society, between advantages and disadvantages

Keywords: Child publicity. Freedom of expression. Advertising regulation. Children and adolescents.

\section{INTRODUÇÃO}

Com a estabilização da economia mundial no pós-guerra e o crescimento das sociedades de consumo em massa, as crianças e adolescentes tornaram-se alvo das cadeias de produção e das empresas de publicidade, objetivando a atração e, consequentemente, o aumento do consumo de produtos específicos para um novo público consumerista, visando ao lucro.

O sucesso foi e continua sendo grande, vez que o público infantil e adolescente é um nicho consumidor importantíssimo, com a utilização de cifras astronômicas em épocas conhecidas pelo comércio, como a tradição natalina de ganhar presentes. Por outro lado, não somente em épocas específicas que as crianças e adolescentes são consumidores em massa, mas sim em todo o ano, pois necessitam, assim como qualquer pessoa, de inúmeros itens para sua subsistência e satisfação de desejos impostos pelos padrões de consumo.

O problema não é consumir, isso é parte da vida de qualquer pessoa, mas sim quando há a disseminação indiscriminada da doutrina do consumismo exacerbado para aqueles que estão em formação, em uma fase de absorção, ainda hipossuficientes, vulneráveis.

É possível encontrar uma relação de variados produtos que possuem como destino o mercado infantil, associados a brindes, personagens infantis, brinquedos, e qualquer outro modo que possa chamar a atenção e mostrar-se como algo "necessário" para a vida daquele jovem. Esse contexto é a realidade não apenas em países desenvolvidos e ditos consumistas natos, como EUA e pela União Europeia, mas também em nações ainda em desenvolvimento, caso de Brasil, China e Índia.

A publicidade é uma importante ferramenta para a atração de consumidores, está em ascensão, é a mantenedora do entretenimento infantil, como os já conhecidos programas televisivos de desenhos infantis, e, além disso, ajuda a movimentar a economia, na geração de empregos, 
na produção e na arrecadação de impostos. É um mercado de dimensões imensuráveis.

Acima de tudo, a publicidade é um direito com proteção constitucional como atividade econômica resguardada pela livre iniciativa, fundamento da ordem econômica (art. 170, caput e parágrafo único, CF) e livre concorrência. (art. 170, IV, CF) e pelo princípio da liberdade de expressão (arts. 5. ${ }^{\circ}$, IX e 220, CF).

Por outro lado, crianças e adolescentes são indivíduos em formação, merecendo uma proteção irrestrita, como preceitua a própria Constituição Federal, que elegeu um tratamento com prioridade a esses indivíduos em seu artigo 227, o qual ainda estabeleceu como sujeitos ativos para assegurarem esse direito a família, a sociedade e o Estado.

Nesse contexto, diante dos efeitos que possa gerar a publicidade veiculada ao público jovem, será possível a liberdade de expressão, na forma de liberdade de publicidade, ser restringida em benefício da proteção integral da criança e adolescente?

Essa não é a única questão, vez que em caso de a resposta à indagação ser positiva, deve ser definida qual a melhor forma de restrição diante dos preceitos de Direito. Um polêmico conflito de direitos constitucionais que será solucionado nesse trabalho através da pesquisa bibliográfica e direito comparado.

O trabalho está organizado logicamente, encontrando-se dividido em quatro partes subsequentes. Trata-se, em um primeiro momento, sobre a liberdade de expressão e sua restrição no Direito brasileiro, através de leve abordagem histórica sobre o tema e características. A explanação sobre o conceito, em âmbito nacional e internacional, de criança e adolescente e a teoria da proteção integral desses indivíduos, aplicada no Brasil e em vários países, realiza uma ponte para tratar da regulamentação da publicidade no país, demonstrando o sistema utilizado, matérias específicas ao público em destaque e uma rápida abordagem por projetos de lei. Ao final, uma análise de Direito Comparado sobre as legislações de regulamentação publicitária em grandes democracias mundiais.

Utilizou-se do método dedutivo, com análise de diplomas legais relacionados ao tema, e a pesquisa em obras de diferentes áreas da ciência, decisões judiciais e ênfase em Direito Comparado, que se mostra importante ferramenta em solução de conflitos jurídicos. Nas considerações, conclui-se que apesar de o sistema de regulamentação publicitária ser misto, integrando a forma privada e a proteção estatal, ainda é falho e 
ineficaz diante da hipossuficiência do público abordado, sendo imprescindível uma lei específica para a regulamentação.

\section{LIBERDADE DE EXPRESSÃO E SUA RESTRIÇÃO}

A liberdade, nas suas diversas espécies, é, conjuntamente com o direito à vida, um dos mais importantes direitos, uma das mais antigas reivindicações dos homens. Sem a liberdade é impossível gozar do poder de escolha, de ser o juiz em suas próprias decisões, de manifestação, de utilizar do livre arbítrio etc. A história demonstra que muitas pessoas preferiram a morte ao ter a liberdade restringida.

O direito à liberdade, fazendo jus à sua importância, é um dos direitos humanos, esses que podem ser conceituados, segundo Alexandre A. Silva:

Aqueles inerentes à pessoa humana pelo simples fato de ser considerada como tal, trazendo consigo os atributos da universalidade, imprescritibilidade, irrenunciabilidade e inalienabilidade, reconhecidos em convenções e tratados internacionais. ${ }^{2}$

Apesar de o conceito de Alexandre A. Silva estar em consonância com maioria dos conceitos de direitos humanos encontrados em obras doutrinárias, não é capaz de transmitir, logo no primeiro momento, o impacto merecido diante da envergadura desses direitos. Nascem os direitos humanos, das lutas sociais e são conquistas históricas da humanidade.

Desse modo, incorreta é a noção de que os direitos humanos são inerentes ao homem pelo simples fato de sua natureza humana, pois essa conceituação seria uma afronta ao fato dos milhares e talvez milhões de pessoas que sofreram em diversas lutas históricas, e continuam nessa luta a nível mundial, para fazer valer não somente o reconhecimento desses direitos, mas a sua aplicação.

Nesse sentido faz-se necessário dizer que as liberdades são um direito de primeira geração, pautadas no princípio da liberdade, como

${ }^{2}$ SILVA, Alexandre Assunção e. Liberdade de expressão e crimes de opinião. São Paulo: Atlas, 2012. p. 156. 
resposta ao Estado absolutista à insatisfação da burguesia. A classe dominante no sentido econômico na época, a burguesia, sentindo-se privada de certa liberdade, não se conformando com o regime de poder concentrado em um monarca, fez eclodir a Revolução Francesa, importante marco para entender o processo vinculado ao reconhecimento e aplicação dos direitos humanos. Os professores de Direito Júlia L. Silva e Vinícius F. Ormelesi conceituam esses direitos de primeira geração como direitos civis e políticos, fruto das Revoluções Liberais-burguesas, (Processo de Independência dos EUA e a Revolução Francesa - séc. XVIII e XIX) da transição do Estado Absolutista para o Estado Liberal de Direito. ${ }^{3}$

Considera-se que a Declaração dos Direitos da Virgínia, ou Bill of Rights de Virgínia, no ano de 1776, e a Declaração dos Direitos do Homem e do Cidadão na Assembleia Nacional Francesa em 1789 são os momentos cruciais em que ocorre a positivação dos direitos inerentes ao homem, passando a serem passíveis de exigência jurídica, inclusive do próprio Estado. ${ }^{4}$

Para o entendimento da razão de um determinado direito ser considerado inerente à própria humanidade, é necessário observar um concurso de condições históricas e sociais favoráveis à incorporação em um estatuto, além das correntes filosóficas. As liberdades foram, então, fruto das lutas sociais nas Revoluções Francesa e Americana, expressando o dito anteriormente, vez que muitos foram os que preferiram lutar até a morte em busca da liberdade ao viver sem ela.

A Constituição Federal de 1988, apropriadamente batizada de Constituição Cidadã, porque era o Brasil, nessa época, um país recémsaído da ditadura militar na qual os princípios constitucionais foram trocados por porões de tortura dos oponentes políticos do militarismo, é considerada uma das mais avançadas do mundo no que toca à proteção dos direitos e garantias individuais. É possível a percepção em seu Preâmbulo, que estabelece que a Assembleia Constituinte teve como objetivo básico a proteção, dentre outros direitos, à liberdade. Esse objetivo do constituinte deve ser utilizado para a interpretação da Carta Magna, e é de fundamental importância para o presente estudo, que possui como

${ }^{3}$ SILVA, Julia Lenzi; ORMELESI, Vinicius Fernandes. Apostila de direitos humanos: 1. ${ }^{\circ}$ Curso Concentrado de Direitos Humanos, Franca, 2015. p. 28. ${ }^{4}$ MENDES, Gilmar Ferreira; BRANCO, Paulo Gustavo Gonet. Curso de direito constitucional. 7. ed. São Paulo: Saraiva, 2012. p. 154. 
objeto o conflito entre direitos, buscando a solução mais adequada ao caso.

É clara a importância da liberdade na humanidade. O ser humano roga por liberdade que é algo natural, pois ele possue opiniões e a tendência de expressá-las. Para essa expressão existir, necessária é uma proteção jurídica, proteção esta alcançada com a liberdade de expressão, uma das espécies do gênero liberdade.

Nesse sentido, a liberdade de expressão é, além de direito humano reconhecido pelas convenções internacionais, um direito fundamental no Brasil, assegurado a todo cidadão, pois está positivado na Constituição Federal de 1988, nos art.5. ${ }^{\circ}$, incisos IV, IX e XIV e art.220, caput e em seus $\S \S 1 .^{\circ}$ e $2 .^{\circ}$. O constituinte se preocupou de tal modo com a proteção desse direito que chegou a ser redundante na descrição pelo texto constitucional, talvez pelo período ditatorial pré-constitucional.

Liberdade de expressão é conceituada por Celso Bastos como:

Direito de exprimir e divulgar livremente o seu pensamento. É o direito de não ser impedido de exprimir-se. Ao titular da liberdade de expressão é conferido o poder de agir, pelo qual contará com a abstenção ou com a não interferência de quem quer que seja no exercício do seu direito. ${ }^{5}$

Através desse direito fundamental previsto em nossa Constituição alcançou-se a proteção contra a censura, fazendo jus a um Estado Democrático de Direito, vez que é fundamental a livre manifestação de pensamento, pois é um instrumento para a preservação da democracia, possibilitando o pluralismo de opiniões, essencial para a formação da vontade livre. Não cabe ao Estado interferir nas expressões que considera ou não válidas, mas sim ao próprio público, que receberá as manifestações e, através do seu livre arbítrio, filtrará os conteúdos. ${ }^{6}$

Importantíssima a ideia de que o cidadão brasileiro deve, através de direito positivado na Constituição Federal, realizar um filtro por si

${ }^{5}$ BASTOS, Celso Ribeiro. Os limites à liberdade de expressão na Constituição da República. Cadernos de direito constitucional e ciência política, São Paulo, n. 20, jul./set. 2007. p. 43.

${ }^{6}$ MENDES, Gilmar Ferreira; BRANCO, Paulo Gustavo Gonet. Curso de direito constitucional. 7. ed. São Paulo: Saraiva, 2012. p. 299 e 301. 
só sobre as diversas matérias objetos de expressão na sociedade. Cada indivíduo está exposto, diuturnamente, ao conteúdo publicitário, por exemplo, e a tendência em uma sociedade capitalista é o foco nessa alavanca para o consumismo. No tema em estudo, será fundamental para um debate conclusivo o ensinamento do reconhecido constitucionalista Gilmar Mendes supratranscrito.

Confere completar a ideia com o ensinamento de Alex Potiguar, ao declarar que "a liberdade de expressão é consagrada como um dos direitos fundamentais mais importantes para a constituição de um governo aberto, plural e democrático, seja pelo seu caráter subjetivo, seja pela sua acepção objetiva. "7

O direito de liberdade de expressão é um dos principais em uma democracia, compreendendo não somente informações consideradas inofensivas, mas também aquelas que possam causar algum transtorno ou resistência, pois a democracia só existe a partir da consagração do pluralismo de ideias e pensamentos, da tolerância de opiniões e do espírito aberto ao diálogo. ${ }^{8}$ Tem por objeto, de acordo com a ideia extraída do art.5. ${ }^{\circ}, \mathrm{IV}$, tudo o que se pode comunicar, toda forma de mensagem, ou seja, juízos, propaganda de ideias e notícias sobre fatos. Logo engloba a liberdade de veicular publicidade. Liberdade de expressão é gênero, possuindo várias espécies, como a liberdade de consciência e crença religiosa, artística, filosófica, científica, e como dito, a de publicidade, que será abordada neste trabalho, dentre outras.

A liberdade de publicidade, como dito, é uma espécie de liberdade de expressão ou uma subespécie do gênero liberdade. É um importante direito com fulcro nas relações econômicas, no âmbito da possibilidade de conhecimento do público consumidor dos produtos e serviços à sua disposição, das diversas empresas e marcas, fomentando a livre concorrência e, consequentemente, o desenvolvimento da economia. Vivemos em um mundo capitalista, e o consumo é parte do dia a dia, é uma prática que todos nós exercemos. Absolutamente ninguém consegue sobreviver sem consumir produtos e serviços, por mais diminutos que possam ser.

${ }^{7}$ POTIGUAR, Alex. Liberdade de expressão e o discurso do ódio: a luta pelo reconhecimento da igualdade como direito à diferença. Brasília: Consulex, 2012. p. 98 .

${ }^{8}$ Ibidem. 


\subsection{RESTRIÇÃO DA LIBERDADE DE EXPRESSÃO}

A liberdade de expressão é um direito fundamental, uma conquista da humanidade e de extrema importância para um Estado Democrático de Direito. O Brasil conquistou uma vitória com a saída do período ditatorial para a democracia ampla e plena. Com absoluta certeza a liberdade de manifestação do pensamento é um dos mais importantes aliados direitos que permitiram essa evolução.

Seria possível, desse modo, a restrição desse direito?

A resposta somente pode ser positiva, vez que não há direito absoluto. Mas o processo não é simples como pode parecer em um primeiro momento, devido ao fato de tratar-se de direitos reconhecidos expressamente na Constituição como fundamentais, inerentes ao ser humano a nível internacional.

Um direito fundamental só poderá ser restringido com base nas reservas constitucionais, no estabelecido previamente no texto maior, restringindo-se apenas por normas de hierarquia constitucional ou em virtude delas. Possibilitará a restrição de um direito fundamental a colisão com outros direitos fundamentais ou princípios constitucionais. Na primeira hipótese, trata-se dos casos especificamente previstos na Constituição, que expressamente autorizam intervenções e restrições. Para a restrição por princípios, somente será possível de acordo com um sopesamento, uma valoração no caso concreto, realizando-se um juízo de ponderação. ${ }^{9}$

Faz-se importante ressaltar a lição de Alexy:

Se dois princípios colidem - o que ocorre, por exemplo, quando algo é proibido de acordo com um princípio e, de acordo com o outro, permitido -, um dos princípios terá de ceder. Isso não significa, contudo, nem que o princípio cedente deva ser declarado inválido, nem que nele deverá ser introduzida uma cláusula de exceção. Na verdade, o

${ }^{9}$ SILVA, Alexandre Assunção e. Liberdade de expressão e crimes de opinião. São Paulo: Atlas, 2012. p. 40. 
que ocorre é que um dos princípios tem precedência em face do outro sob determinadas condições. ${ }^{10}$

Desse modo, será possível a restrição de direitos fundamentais, mas de acordo com um sopesamento realizado entre os direitos conflitantes, observando-se, no caso concreto, se a satisfação do direito privilegiado está de acordo com o interesse constitucional, permitindo assim a restrição do outro.

Partindo da ideia de que nenhum direito fundamental é absoluto, passível a conclusão de estar inserido nas possíveis limitações o direito de liberdade de expressão. Esse direito poderá ser restringido quando apresentar um claro e presente perigo à sociedade, ou quando ofender um bem jurídico de outrem, bem este fundamental.

Possui hipóteses restritivas no próprio texto constitucional, como pode ser observado no art. $5 .^{\circ}, \mathrm{V}, \mathrm{X}$ e $\mathrm{XLI}, \mathrm{CF}$, in verbis:

Art. 5. ${ }^{\circ}$ Todos são iguais perante a lei, sem distinção de qualquer natureza, garantindo-se aos brasileiros e aos estrangeiros residentes no País a inviolabilidade do direito à vida, à liberdade, à igualdade, à segurança e à propriedade, nos termos seguintes:

(...)

V- é assegurado o direito de resposta, proporcional ao agravo, além da indenização por dano material, moral ou à imagem;

(...)

X- são invioláveis a intimidade, a vida privada, a honra e a imagem das pessoas, assegurado o direito à indenização pelo dano material ou moral decorrente de sua violação;

(...)

XII - é inviolável o sigilo da correspondência e das comunicações telegráficas, de dados e das comunicações telefônicas, salvo, no último caso, por ordem judicial, nas hipóteses previstas e na forma que a lei estabelecer para fins de investigação criminal ou instrução processual penal;

${ }^{10}$ ALEXY, Robert. Teoria dos direitos fundamentais. Trad. Virgílio Afonso da Silva. São Paulo: Malheiros, 2008. p. 123. 
(...)

XLI - a lei punirá qualquer discriminação atentatória dos direitos e liberdades fundamentais;

Nesse mesmo artigo 5. ${ }^{\circ}$, é encontrada uma norma que prevê, expressamente, a proteção do consumidor, e merece destaque diante do contexto em que está inserido o trabalho atual, como assevera o seu inciso XXXII: "XXXII - o Estado promoverá, na forma da lei, a defesa do consumidor";

Há outras restrições previstas diretamente na Magna Carta, como as que dizem respeito à indicação de faixa etária para diversões e espetáculos públicos, publicidade de tabaco, bebidas alcoólicas, agrotóxicos, medicamentos e terapias; produção e programação das emissoras de rádio e televisão, como é possível observar da leitura do artigo $220, \S 4$. $^{\circ}$ da CF:

Art. $220(\ldots) \S 4 .^{\circ}$ - A propaganda comercial de tabaco, bebidas alcoólicas, agrotóxicos, medicamentos e terapias estará sujeita a restrições legais, nos termos do inciso II do parágrafo anterior, e conterá, sempre que necessário, advertência sobre os malefícios decorrentes de seu uso.

A própria Convenção sobre os Direitos da Criança estabelece o direito de liberdade de expressão às crianças, mas ao mesmo tempo reconhece possíveis limitações, como exemplifica a norma de seu texto:

Artigo 13 - 1. A criança terá o direito à liberdade de expressão; este direito incluirá a liberdade de buscar, receber e transmitir informações e idéias de todos os tipos, independentemente de fronteiras, de forma oral, escrita ou impressa, por meio das artes ou por qualquer outro meio da escolha da criança.

2. O exercício desse direito poderá sujeitar-se a certas restrições, que serão somente as previstas em lei e consideradas necessárias:

a) ao respeito dos direitos e da reputação de outrem; 
b) à proteção da segurança nacional ou da ordem pública ordre public, ou da saúde e moral públicas. ${ }^{11}$

O discurso de ódio é mais um apontamento importante de restrição da liberdade de expressão. Pode ser definido como dispersão de ódio e incitação à discriminação, hostilidade e violência contra uma pessoa ou grupo em virtude de raça, religião, nacionalidade, orientação sexual, gênero, condição física ou outra característica de um determinado grupo. ${ }^{12}$

O catastrófico episódio ocorrido na Alemanha com o povo judeu durante a Segunda Guerra Mundial conhecido como Holocausto, exemplo prático de discurso de ódio contra um determinado grupo de pessoas diante de sua característica, e que acarretou consequências imensuráveis, acabou provocando a sua limitação em diversos países, como forma preventiva de evitar eventos semelhantes.

No Brasil, apesar de não existir uma regulamentação legal específica, o STF em julgamento do famoso caso Ellwanger ${ }^{13}$ em 2003, entendeu pela ilicitude do discurso de ódio, por 7 votos a três, com a fundamentação exemplar do Ministro Gilmar Mendes, pautando seu voto no fato da liberdade de expressão não ser absoluta, sofrendo limitações pela dignidade humana, por exemplo, e que deve ser restringida através do princípio da proporcionalidade. ${ }^{14}$

Inúmeras decisões judiciais e leis trazem vários outros exemplos de limites da liberdade de expressão no Brasil. Podemos citar o artigo 286 do Código Penal Brasileiro, que tipifica o delito de Incitação ao Crime, estabelecendo que é conduta criminosa incitar, instigar, provocar ou estimular a prática de crime; o artigo 287, do mesmo diploma, tipificando o delito de Apologia ao Crime, cujo núcleo do tipo é elogiar, lou-

${ }^{11}$ BRASIL. Convenção Sobre os Direitos da Criança. Decreto no 99.710 de 21 de Novembro de 1990. Disponível em: <http://www.planalto.gov.br/ccivil 03/decreto/1990-1994/D99710.htm>. Acesso em: 08.Jun.2015.

${ }^{12}$ ARTICLE 19. Panorama sobre o discurso de ódio no Brasil. Disponível em: <http://artigo19.org/centro/files/discurso_odio.pdf〉. Acesso em: 22.Jun.2015. p. 1.

${ }^{13}$ Ibidem. p. 11.

${ }^{14}$ SUPREMO TRIBUNAL FEDERAL. Notícias. STF nega Habeas Corpus a editor de livros condenado por racismo contra judeus. Disponível em: $<\mathrm{http} / / / \mathrm{www}$.stf.jus.br/portal/cms/verNoticiaDetalhe.asp?idConteudo=61291>. Acesso em 25.Jun.2015. 
var o crime ou o autor deste, sendo o dolo a vontade de fazer apologia incriminada com a ciência que está se atingindo número indeterminado de pessoas. Por fim, para encerrar a exemplificação, devem constar os delitos de injúria, difamação e calúnia como algumas hipóteses em que o direito de liberdade de expressão sofre limites.

Como se observa nas normas acima referidas, principalmente nas de cunho constitucional, passível a conclusão da existência de limites expressos na Constituição Federal à liberdade de publicidade, regulando a possibilidade de sofrer restrições toda publicidade que estimular práticas de consumo potencialmente não saudáveis, ou sempre que determinada atividade publicitária colocar em risco a saúde e a qualidade de vida dos consumidores. Desse modo, como assevera Igor Rodrigues Britto, é possível estender os limites da liberdade publicitária a outros princípios e direitos fundamentais da Constituição, como a saúde, a vida e a dignidade humana. ${ }^{15}$

Importante ressaltar, pelo tema, a proteção integral da criança e adolescente, teoria adotada pela nossa Constituição e que será abordada em momento oportuno, fundamento principal para a restrição de qualquer direito fundamental que atente contra os interesses dos jovens, vez que o texto constitucional deixou clara a "absoluta prioridade" que deve ser dada à criança e ao adolescente. É dever do Estado, da sociedade e da família assegurar a esses jovens o direito à vida, à educação, à dignidade e à liberdade, fixando-se o propósito de resguardá-los de toda forma de discriminação, violência, exploração, crueldade e opressão, como estabelece o art.227 da $\mathrm{CF}^{16}$.

Previsto isso na Magna Carta, é cabível que a liberdade de expressão poderá ser limitada quando o seu conteúdo colocar em risco a criança e adolescente. Em um contexto que estimule e exponha a juventude à exploração de toda sorte, inclusive a comercial, tende a ceder ao valor prioritário da proteção da infância e da adolescência. ${ }^{17}$

${ }^{15}$ BRITTO, Igor Rodrigues. Infância e publicidade: proteção dos direitos fundamentais da criança na sociedade de consumo. 1. ed. Curitiba: CRV, 2010. p. 147.

${ }^{16}$ BRASIL. Constituição da República Federativa do Brasil de 1988. Disponível em: <http://www.planalto.gov.br/ccivil_03/constituicao/ConstituicaoCom pilado.htm>. Acesso em 02.Ago.2015.

${ }^{17}$ MENDES, Gilmar Ferreira; BRANCO, Paulo Gustavo Gonet. Curso de direito constitucional. 7. ed. São Paulo: Saraiva, 2012. p. 308. 
Necessário será, para o tema abordado, analisar se qualquer forma de publicidade é passível de colocar em risco a criança e adolescente.

Toda restrição, principalmente a de algum direito fundamental, deve observar o princípio da proporcionalidade, sempre restringindo ao mínimo o direito em rota de colisão com o preservado. É, ainda, possível e recomendado, que se proceda a conciliação dos direitos colidentes, de acordo com o caso concreto.

\subsection{CÓDIGO DE DEFESA DO CONSUMIDOR}

O Código de Defesa do Consumidor considera o consumidor como parte vulnerável da relação de consumo. Para tanto, estabelece normas de proteção e defesa do consumidor, em consonância com o previsto no art. $220, \S 4 .^{\circ}$ da $\mathrm{CF}$, supratranscrito e comentado, e tais normas possuem caráter de ordem pública.

Ocupou-se apenas da publicidade e não da propaganda, estabelecendo normas de regulamentação em face da proteção do público destinatário em geral, o consumidor, criando formas de restrição publicitária, o que implicou, dentro do contexto abordado por este trabalho, em modos de restrição da liberdade de expressão, na sua modalidade liberdade de publicidade.

Ao ocupar-se de normas referente à regulamentação da publicidade no Brasil, o Código de Defesa do Consumidor inaugurou o sistema "misto" de regulamentação, instaurado atualmente no país. Anteriormente havia apenas o sistema Privado, vez que a regulamentação era exclusividade do CONAR, ONG vinculada às próprias empresas publicitárias através da adesão ao Código Brasileiro de Autorregulamentação Publicitária.

Desse modo, atualmente a regulamentação ocorre por um sistema que conjuga ambas as hipóteses, pois a publicidade deve seguir a regulamentação pelo CONAR, observando atentamente o CBAP, podendo sofrer, em caso de descumprimento, sanções administrativas. Por outro lado, as agências de publicidade devem seguir o expresso no Código de Defesa do Consumidor, Lei Federal, e passível de punição judicial nos casos de inobservância. 
No Capítulo V, Seção III, do CDC, especificamente nos artigos 36, 37 e 38, há a previsão das normas referentes à prática publicitária. Nos dois primeiros há hipóteses de restrição, ocupando-se o último de norma referente ao ônus da prova.

rt. 36. A publicidade deve ser veiculada de tal forma que o consumidor, fácil e imediatamente, a identifique como tal.

Parágrafo único. $\mathrm{O}$ fornecedor, na publicidade de seus produtos ou serviços, manterá, em seu poder, para informação dos legítimos interessados, os dados fáticos, técnicos e científicos que dão sustentação à mensagem.

Art. 37. É proibida toda publicidade enganosa ou abusiva.

$\S 10^{\circ}$ - É enganosa qualquer modalidade de informação ou comunicação de caráter publicitário, inteira ou parcialmente falsa, ou, por qualquer outro modo, mesmo por omissão, capaz de induzir em erro o consumidor a respeito da natureza, características, qualidade, quantidade, propriedades, origem, preço e quaisquer outros dados sobre produtos e serviços.

$\S 2 .^{\circ}$ - É abusiva, dentre outras a publicidade discriminatória de qualquer natureza, a que incite à violência, explore o medo ou a superstição, se aproveite da deficiência de julgamento e experiência da criança, desrespeita valores ambientais, ou que seja capaz de induzir o consumidor a se comportar de forma prejudicial ou perigosa à sua saúde ou segurança.

$\S 3 .^{\circ}$ - Para os efeitos deste código, a publicidade é enganosa por omissão quando deixar de informar sobre dado essencial do produto ou serviço.

Art. 38. O ônus da prova da veracidade e correção da informação ou comunicação publicitária cabe a quem as patrocina.

Diante da análise do artigo 36, extrai-se que é vedada qualquer prática de publicidade subliminar, a qual pode ser conceituada como aquela que se faz de maneira oculta, atingindo o subconsciente do interlocutor. Trata-se de publicidade proibida, visto que expõe o consumidor a 
condição de fraqueza, abordando-o de forma a torná-lo mais sugestionável, limitando, assim, sua liberdade de escolha. ${ }^{18}$

No artigo 37, estão previstas a publicidade enganosa e abusiva, conceituando ambas as práticas. Sobre a modalidade prevista no $\S 1 .^{\circ}$ e $3 .^{\circ}$ do referido artigo, a enganosa, conclui-se essencialmente que publicidade enganosa é toda aquela que por ação ou omissão induza o consumidor a erro sobre dados essenciais do produto ou serviço. Trata-se, obviamente, de publicidade terminantemente repudiada pelo sistema consumerista. ${ }^{19}$

Por fim, a publicidade abusiva, prevista e conceituada no $\$ 2 .^{\circ}$ do artigo 37 e que pode ter sua essência traduzida como aquela que se aproveite da vulnerabilidade do consumidor, ou que viole valores sociais e morais do mesmo, da mesma forma é vedada. Importante ressaltar que o CDC adotou conceitos abertos, permitindo que se amplie a interpretação em benefício da proteção do consumidor.

Como dito anteriormente, o Código de Defesa do Consumidor acabou por criar formas de restrição à liberdade de expressão, em sua modalidade liberdade de publicidade, baseado no princípio de proteção do consumidor, a parte vulnerável da relação de consumo.

Cabe destacar a referência que faz o $\$ 2 .^{\circ}$, ao definir o que é publicidade enganosa, utilizando no rol exemplificativo como sendo aquela, dentre outras, a que "se aproveite da deficiência de julgamento e experiência da criança".

É possível observar que muitas são as hipóteses de restrição da liberdade de expressão, como ressaltado através da exemplificação acima. Desse modo, clara é a possibilidade de direitos, mesmo que fundamentais, serem restringidos, visto que não há direito absoluto, e desde que seja algo proporcional, para satisfazer direito de mesmo valor ou superior, dependendo da análise do caso concreto.

Realizando uma síntese entre as ideias expressas acima, é possível concluir que a liberdade de expressão, como um dos direitos humanos positivados em nossa Constituição, é da maior importância para um Estado Democrático de Direito, para a vida em sociedade, para a manifestação do pensamento etc.

${ }^{18}$ SPERANZA, Henrique de Campos Gurgel. Publicidade enganosa e abusiva. Disponível em: <http://www.ambitojuridico.com.br/site/?nlink=revistaartigosleit ura\&artigoid=11909>. Acesso em: 06. Abr. 2015.

${ }^{19}$ Ibidem. 
Por outro lado, apesar da sua extrema importância e relevância, de todas as lutas necessárias para o seu reconhecimento e aplicação, o direito de liberdade de expressão pode ser restringido, diante do princípio de que não há direito absoluto.

Nesse sentido é possível ver exemplos de restrição em várias situações, como os exemplos do Código de Defesa do Consumidor e da própria Magna Carta, já na modalidade liberdade de publicidade.

O princípio da proporcionalidade de Robert Alexy deve ser utilizado nas ocasiões de restrição da liberdade de expressão, em qualquer de suas modalidades, para a proteção de um direito de igual ou maior valor, de acordo com o caso concreto. Um direito fundamental, antes de restringido, deve ser pautado por um estudo profundo e detalhado.

Claro, o grande problema é definir em quais casos haverá um direito de importância tal que permita a restrição da liberdade de expressão, diante da árdua tarefa de sopesamento e da imensa responsabilidade.

Enfim, com toda certeza, é um tema complexo e merecedor de estudo.

\section{CONCEITO DE CRIANÇA E ADOLESCENTE E TEORIA DA PROTEÇÃO INTEGRAL.}

Para as normas internacionais o termo "criança" é utilizado para definir, indistintamente, todos com idade inferior a 18 anos, norma essa que está expressa na Convenção sobre os Direitos da Criança, da qual o Brasil é signatário desde o ano de 1990. Apenas no âmbito nacional é realizada a distinção entre os termos "criança" e "adolescente", sendo, em algumas vezes, de extrema importância, pelo fato do legislador estabelecer, em certos e determinados casos, um tratamento diferenciado. ${ }^{20}$

No Direito pátrio, a definição de criança é a pessoa com até 12 anos de idade, como estabelece o Estatuto da Criança e do Adolescente em seu artigo segundo.

${ }^{20}$ DIGIÁCOMO, Murillo José; DIGIÁCOMO, Ildeara Amorim. Estatuto da criança e do adolescente anotado e interpretado. 6. ed. Curitiba: Ministério Público do Estado do Paraná - Centro de Apoio Operacional das Promotorias da Criança e do Adolescente, 2013. p. 289. 
Neste mesmo dispositivo está conceituado o adolescente, como o indivíduo entre 12 e 18 anos de idade. Essa definição corresponde à ciência da Psicologia, que através de seus estudos determina esse critério objetivo, como o limite mínimo para que o indivíduo passe pelo processo completo de desenvolvimento cognitivo e moral, estando, dessa forma, minimamente capacitado para o exercício de sua autonomia.

Antes de prosseguir com o estudo, valoroso dizer que a criança, em seu sentido "internacional" (compreendendo todos com idade inferior a 18 anos) merece uma proteção especial por se encontrar em uma situação única, um estágio incompleto de desenvolvimento. Isso não constitui sinônimo de ser a criança um ser totalmente incapaz, mas sim o fato de que passa por uma fase especial, a qual merece atenção devido às suas

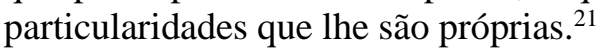

Somente conhecendo do conceito de criança e adolescente será possível entender o Estatuto da Criança e do Adolescente e as polêmicas que o rodeiam, inclusive a Teoria da Proteção Integral. Antes, necessário se faz saber que não é um conceito único e exclusivo da ciência jurídica, pois várias são as ciências que auxiliaram o legislador brasileiro nessa tarefa. $^{22}$

Nesse sentido esclarece Igor Rodrigues Britto:

Qualquer estudo sobre a proteção da criança, seja qual for o seu contexto, demanda o entendimento prévio do pesquisador sobre a fase da vida que compõe a infância, numa análise que extrapola o mero estudo do fenômeno jurídico envolvido. Para consolidar premissas e realizar a correta interpretação da Lei, não basta compreendê-la isoladamente, mas sim a partir de fundamentos

${ }^{21}$ BRITTO, Igor Rodrigues. Infância e publicidade: proteção dos direitos fundamentais da criança na sociedade de consumo. 1. ed. Curitiba: CRV, 2010. p. 23.

${ }^{22}$ Ibidem. p. 21. 
transdisciplinares (pela antropologia, sociologia, psicologia e pedagogia) que a compuseram. ${ }^{23}$

O conceito de criança evoluiu com o tempo, ao lado da transformação da sociedade. Durante séculos, aliás, não havia diferenciação entre adultos, crianças e adolescentes. Todos eram tratados da mesma forma, com as mesmas tarefas, rotina e vestimentas, sendo a criança apenas um "mini-adulto" ou adulto em miniatura.

Somente a partir dos séculos XV e XVI, houve os primeiros resquícios dessa diferenciação, momento no qual "iniciou" a existência desses seres. Essa nova ideologia, apesar de uma evolução extremamente morosa, que se entendeu por vários séculos, é de suma importância para o desenvolvimento social. A partir desse marco histórico, a classe infantil começou a ser destinatária de tratamento distinto daquele da classe adulta, através de uma renovação dos métodos educacionais, de forma que se enquadrasse à personalidade da criança, momento em que, com o advento das instituições de ensino, ela foi retirada do encargo de tarefas delegadas aos adultos. ${ }^{24}$

Atualmente, as demais ciências que tratam do tema criança, como a psiquiatria infantil, pediatria, psicologia, pedagogia, neurologia dentre outras, possuem como ponto em comum o fato de a infância ser um período, uma fase de adaptação necessária àquele indivíduo, que será introduzido no mundo adulto. Vários estudos apontam, inclusive, que as experiências vivenciadas durante essa fase inicial da vida são as explicações de vários comportamentos dos indivíduos na fase adulta. Um desses comportamentos, o qual é extremamente comum na sociedade capitalista atual, é o consumismo. ${ }^{25}$

Deve ser ressaltado o fato de que apesar de já nos séculos XV e XVI estar instituída, dentro da sociedade, uma leve percepção do conceito

${ }^{23}$ BRITTO, Igor Rodrigues. Infância e publicidade: proteção dos direitos fundamentais da criança na sociedade de consumo. 1. ed. Curitiba: CRV, 2010. p. 21.

${ }^{24}$ PORTO, Renato. Publicidade digital: proteção da criança e do adolescente. São Paulo: Saraiva, 2014. p. 13-14.

${ }^{25}$ BRITTO, Igor Rodrigues. Infância e publicidade: proteção dos direitos fundamentais da criança na sociedade de consumo. 1. ed. Curitiba: CRV, 2010. p. 22. 
de criança, isso não significou um tratamento com prioridade ou proteção integral, mas pelo contrário.

\section{Segundo João Paulo Roberti Junior:}

Dessa forma, ainda no século XVII surgiram os castigos, a punição física, os espancamentos com chicotes, ferros e paus, com o pretexto de que as crianças precisavam ser afastadas de más influências, bem como deveriam ser moldadas conforme o desejo dos adultos. Nesse sentido, entre 1730 e 1779, metade das pessoas que morreram em Londres tinha menos de cinco anos de idade. ${ }^{26}$

Passível a percepção de que por um majorado período da história da humanidade, apesar de começar a ser parte integrante da sociedade o pensamento de que as crianças não eram adultos em miniatura, mas sim um indivíduo único, com a incapacidade de ser portador das mesmas tarefas do resto do mundo, ainda deveriam ser oprimidas de qual forma fosse necessário, com o objetivo de amoldarem-se rápida e eficientemente à vida que lhes aguardava no futuro próximo.

Vários são os exemplos de entidades escolares administradas pela Igreja Católica, as quais cultuavam o ensino a qualquer custo, utilizando de castigos morais e físicos. Poucas décadas atrás, no Brasil, encontravam-se resquícios desse método retrógrado de ensino, o qual desapareceu nos colégios modernos.

Somente no século XX, marcado por intensas transformações sociais e grandes impactos mundiais, surgiu e tornou-se forte a ideia de que a criança necessita de um tratamento diferenciado. Nesse sentido, a primeira manifestação dos direitos infantojuvenis ocorreu em 1919, quando foi criado o Comitê de Proteção da Infância, consolidando no Direito Internacional as obrigações coletivas em relação às crianças. Com isso, o reconhecimento da titularidade de proteção dessa população, deixa de ser o Estado o único detentor sobre a matéria. Mais tarde, surge a primeira Declaração dos Direitos da Criança que veio recomendar que os

\footnotetext{
${ }^{26}$ ROBERTI JUNIOR, João Paulo. Evolução jurídica do direito da criança e do adolescente no Brasil. Revista da Unifebe (online). 2012. p. 4.
} 
Estados filiados devessem ter suas próprias legislações em defesa aos direitos das crianças e da juventude. ${ }^{27}$

Realizando uma síntese sobre a evolução mais recente da proteção da criança e adolescente, é possível estabelecer que o primeiro grande marco concernente à proteção social foi na Convenção Internacional sobre os Direitos da Criança, ${ }^{28}$ documento que ditou as bases para o estabelecimento da doutrina da proteção integral. A convenção pode ser definida como um tratado que visa à proteção de crianças e adolescentes de todo o mundo, aprovada na Resolução 44/25 da Assembleia Geral das Nações Unidas, em 20 de novembro de 1989. Dentre os princípios consagrados pela Convenção, estão o direito à vida, à liberdade e as obrigações dos pais, da sociedade e do Estado em relação à criança e adolescente.

Essa convenção conta com grandessíssima adesão, da qual são signatários um expressivo número de Estados, vez que acabou ratificada pela quase totalidade dos Estados-membros das Nações Unidas com a exceção de Somália e Estados Unidos da América.

Vale mencionar alguns artigos contidos em seu texto, dos quais é possível a extração de algumas normas referentes ao tema:

\section{Artigo 17.}

Os Estados Partes reconhecem a função importante desempenhada pelos meios de comunicação e zelarão para que a criança tenha acesso a informações e materiais procedentes de diversas fontes nacionais e internacionais, especialmente informações e materiais que visem a promover seu bem-estar social, espiritual e moral e sua saúde física e mental. Para tanto, os Estados Partes:

a) incentivarão os meios de comunicação a difundir informações e materiais de interesse social e cultural para a criança, de acordo com o espírito do artigo 29; b) promoverão a cooperação internacional na produção, no intercâmbio e na divulgação dessas

${ }^{27}$ ROBERTI JUNIOR, João Paulo. Evolução jurídica do direito da criança e do adolescente no Brasil. Revista da Unifebe (online). 2012. p. 4.

${ }^{28}$ BRASIL. Convenção Sobre os Direitos da Criança. Decreto ${ }^{\circ} 99.710$ de 21 de Novembro de 1990. Disponível em: <http://www.planalto.gov.br/ccivil 03/decreto/1990-1994/D99710.htm>. Acesso em: 08.Jun.2015 
informações e desses materiais procedentes de diversas fontes culturais, nacionais e internacionais;

c) incentivarão a produção e difusão de livros para crianças;

d) incentivarão os meios de comunicação no sentido de, particularmente, considerar as necessidades lingüísticas da criança que pertença a um grupo minoritário ou que seja indígena;

e) promoverão a elaboração de diretrizes apropriadas a fim de proteger a criança contra toda informação e material prejudiciais ao seu bem-estar, tendo em conta as disposições dos artigos 13 e 18.

Artigo 27. 1. Os Estados Partes reconhecem o direito de toda criança a um nível de vida adequado ao seu desenvolvimento físico, mental, espiritual, moral e social.

Artigo 36. Os Estados Partes protegerão a criança contra todas as demais formas de exploração que sejam prejudiciais para qualquer aspecto de seu bemestar. $^{29}$

O primeiro artigo apontado, o de número 17, pode ser considerado com uma síntese dos temas abordados até o momento. Inicialmente, assegura o direito aos meios de comunicação, acesso de informação e materiais, declarando a necessidade de incentivo do Estado. Por outro lado, na parte final do caput está prevista a especialidade de atenção a ser dada para as fontes que "visem a promover seu bem-estar social, espiritual e moral e sua saúde física e mental", algo que já pode ser considerado como uma limitação em função da situação peculiar em que se encontra a criança e o adolescente. A alínea $\mathrm{E}$ acaba por deixar mais óbvio essa possível limitação, estabelecendo que os Estados devam elaborar "diretrizes apropriadas a fim de proteger a criança contra toda informação e material prejudiciais ao seu bem-estar", caso em que se pode enquadrar, em uma avaliação preliminar, a publicidade dirigida ao público infantil.

Os artigos 27 e 36 ainda esclarecem, de maneira translúcida, a necessidade de propiciar aos jovens elementos para seu regular desenvol-

\footnotetext{
${ }^{29}$ BRASIL. Convenção Sobre os Direitos da Criança. Decreto n ${ }^{\circ} 99.710$ de 21 de Novembro de 1990.1 Disponível em: <http://www.planalto.gov.br/ccivil03/decreto/1990-1994/D99710.htm>. Acesso em: 08.Jun.2015.
} 
vimento físico, mental, espiritual, moral e social, e que é função dos Estados signatários de procederem em defesa, erradicando qualquer forma de exploração que possa acarretar prejuízos.

O Brasil aderiu à Convenção Internacional sobre os Direitos da Criança em 1990, mesmo ano de promulgação do Estatuto da Criança e do Adolescente (Lei n. ${ }^{\circ}$ 8.069), lei de caráter inovador, sendo o país um dos percursores em legislação específica destinada à proteção dos jovens da sociedade. O ECA, como é conhecido, pode ser considerado uma consequência da adesão à Convenção supramencionada. O Estatuto é reconhecido, internacionalmente, como um dos mais avançados Diplomas Legais dedicados à garantia dos direitos da população infanto-juvenil.

No mesmo ano, ficou estabelecido pela Cúpula Mundial de Presidentes o plano de ação de 10 anos em favor da infância. No ano seguinte, o Brasil veio a adotar oficialmente o Pacto de São Juan da Costa Rica, e em 1996, foram instituídas as Regras Mínimas das Nações Unidas, visando à proteção dos Jovens Privados de Liberdade. ${ }^{30}$

Em nível nacional, devem ser aprofundados a Constituição Federal e o Estatuto da Criança e do Adolescente. A partir de 1988, crianças e adolescentes são reconhecidos na condição de sujeitos de direitos e não meros objetos de intervenção no mundo adulto, consagrando a Teoria da Proteção Integral, a qual se confronta com a adotada anteriormente, conhecida como Teoria da Situação Irregular.

Essa teoria, em um singelo resumo, conhecida mundialmente, era utilizada pela legislação nacional pré-Constituição de 1988, e trazia como característica principal o fato de as crianças assumirem a condição de objeto de interesse "jurídico", em determinadas situações, como pela prática de infrações ou pela própria condição de exclusão social que as colocava em evidência. Desse modo, somente interessaria ao universo jurídico a criança e adolescente no exato momento em que cometessem uma infração.

Era a teoria consagrada no antigo Código de Menores, e na visão de alguns doutrinadores, essa retrógrada ideologia refletia uma característica social de exclusão, como citado nas palavras de Lima:

${ }^{30}$ ROBERTI JUNIOR, João Paulo. Evolução jurídica do direito da criança e do adolescente no Brasil. Revista da Unifebe (online). 2012. p. 07. Disponível em <http://www.unifebe.edu.br/revistadaunifebe/20121/artigo025.pdf>. Acesso em: $15 / 07 / 2015$. 
[...] o modelo jurídico menorista, representado pelo binômio 'Código de Menores/Doutrina Jurídica da Situação Irregular', não era apenas uma forma de controle individualizado dos menores irregulares. Era também uma forma de se projetar o controle social numa perspectiva de classe. A partir do padrão de organização da família burguesa, como 'célula mater da nação brasileira', impunha-se traçar o destino, estabelecer os valores morais, o perfil das relações inter-familiares, a lógica dos comportamentos, a serem adotados pelos setores populares. Este era o caminho disponível à sua redenção das famílias pobres, sob pena de serem contra elas movidas as engrenagens do Sistema legal menorista. ${ }^{31}$

Superada essa breve referência da antiga teoria adotada pela legislação, prosseguir-se-á ao estudo da hegemônica Teoria da Proteção Integral, atualmente adotada. Dentro deste tópico, cumpre ressaltar da Magna Carta o artigo 227, o dispositivo responsável pela adoção da teoria supramencionada, que possibilitou um fundamental avanço no que diz respeito ao tratamento nacional adotado com os jovens até 18 anos de idade.

Essa ideologia consagrava-se no Brasil desde o início da década de 1980, através dos estudos jurídicos, enquadrando-se perfeitamente na atual situação nacional, a qual era de democratização, da luta por direitos e garantias individuais. A hegemonia da proteção integral se fazia clara, e outro não poderia ser o destino, este já tardio.

O ser humano em sua fase inicial de vida é mais vulnerável e imaturo, e sofre, mais facilmente, interferência do que recebe do mundo exterior. Toda sociedade está vinculada a sua formação, que perpassa pela integração dos estímulos afetivos, motivações e instrução que chegam à pessoa menor de idade. Sem esse cuidado por parte de todos, não seria atendida a prioridade prevista no art. 227 da Constituição Federal.

${ }^{31}$ LIMA, Miguel M. Alves. O direito da criança e do adolescente: fundamentos para uma abordagem principiológica. Tese (Doutorado em Direito) - Curso de Pós-Graduação em Direito, Universidade Federal de Santa Catarina, Florianópolis, 2001. p. 62. 
Para demonstrar como o ser humano é altamente influenciável, principalmente nos primeiros anos de vida, Maria Lúcia de Arruda Aranha e Maria Helena Pires Martins assim estabeleceram:

O mundo cultural é um sistema de significados estabelecidos por outros, de modo que, ao nascer, a criança encontra o mundo de valores já dados, onde ela vai se situar. A língua que aprende, a maneira de se alimentar, o jeito de se sentar, andar, correr, brincar, o tom da voz nas conversas, as relações familiares; tudo, enfim, se acha codificado. Até na emoção, que nos parece uma manifestação tão espontânea, ficamos à mercê de regras que educam desde a infância a nossa expressão. ${ }^{32}$

O próprio Estatuto da Criança e Adolescente reconhece uma capacidade progressiva de decisão autônoma, porém trata-se de capacidade de uma pessoa em desenvolvimento, razão pela qual não possui plena capacidade. Essa capacidade reduzida torna-se necessária justamente para a proteção de seus interesses atuais e futuros.

Antônio Jorge Pereira Júnior menciona em sua obra:

Para se autodeterminar segundo padrão de comportamento adequado à dignidade humana, a pessoa deve ser bem instruída e deve ser estimulada a agir bem. A criança e o adolescente, em especial estágio de evolução, são passíveis de sofrer interferências de modo mais proeminente que uma pessoa adulta. Necessitam de estímulos e informações que potencializem o melhor uso de sua liberdade. Não dispõem de plena maturidade para julgar e agir bem, por si mesmas, diante das ofertas e estímulos que recebem da vida em sociedade. ${ }^{33}$

${ }^{32}$ ARANHA, Maria Lúcia de Arruda; MARTINS, Maria Helena Pires. Filosofando. 3. ed. São Paulo: Moderna, 2003. p. 173.

${ }^{33}$ PEREIRA JÚNIOR, Antonio Jorge. Direitos da criança e do adolescente em face da TV. São Paulo: Saraiva, 2011. p. 275. 
As crianças são mais impulsivas: como elas vêem e escutam elas aprendem e digerem o que estão observando. Seguem os exemplos e elas criam suas próprias individualidades baseado numa mistura de fatos. A capacidade de atenção atinge maior maturação entre os 6 e 8 anos, mas, por outro lado a capacidade de refletir e interpretar ocorre mais tardiamente. $^{34}$

Límpida é a ideia de a criança e o adolescente serem realmente seres em desenvolvimento em todos os sentidos, sendo sujeitos merecedores de uma maior atenção e preocupação por parte de toda a sociedade.

\subsection{A INFLUÊNCIA DA PUBLICIDADE NA CRIANÇA E ADOLESCENTE}

Há algum tempo o público infanto-juvenil tornou-se uma parcela bastante lucrativa do mercado consumidor global. Historicamente, a nível mundial, após a Segunda Guerra Mundial houve a estabilização da economia e um significativo aumento do número de crianças, vez que em apenas cinco anos o seu número, no mundo, cresceu volumosos cinquenta por cento. Com o surgimento das conhecidas "mesadas", quantidade de dinheiro dada pelos pais aos filhos para gastarem da maneira que lhes for conveniente, e a chegada e expansão rápida da televisão no mundo, as crianças foram apresentadas ao fabuloso mundo do consumo. Logo os empresários perceberam o importante mercado em potencial existente, e eivaram esforços para alcançá-lo em busca de lucros. ${ }^{35}$

Cada vez mais é evidente a entrega dos jovens ao consumo: suas rotinas, seu ócio, suas vidas diárias são destinadas a esse fim. Da mesma forma do que ocorre no mundo adulto, o universo infantil parece se dirigir ao mesmo destino: o de viver para consumir.

Nos dias atuais, com a postergação do nascimento dos filhos, o menor número de crianças por família, e com o forte posicionamento da mulher no mercado de trabalho, atingindo um merecido local de destaque,

${ }^{34}$ ALVAREZ, Ana Maria Blanco Montiel; PASQUALOTTO, Adalberto. (Org.) Publicidade e proteção da infância. Porto Alegre: Livraria do Advogado, 2014. p. 25.

${ }^{35}$ BRITTO, Igor Rodrigues. Infância e publicidade: proteção dos direitos fundamentais da criança na sociedade de consumo. 1. ed. Curitiba: CRV, 2010. p. 25 . 
as famílias se transformaram e, como conseqüência, os pais passaram a ter menos tempo para os filhos, e por vezes, mesmo que de forma inconsciente, procuram compensar a sua ausência comprando-lhes coisas. E, ao chegarem a casa, cansados de mais um dia exaustivo de trabalho, utilizam-se dos mais variados artifícios para poder entreter as crianças, como TV, internet, games etc. Sim, a família também possui sua parcela de culpa no consumismo dos jovens, mas por outro lado não pode receber toda a responsabilidade, como expressa o texto:

Mas a culpa sempre recai nos ombros dos pais. Somente dos pais? Temos também a omissão das escolas que incentivam todas essas datas comerciais. Temos também a sociedade que empurra as crianças a serem cada dia adultas mais cedo. Os pais conseguem ser mais fortes que tantos apelos o tempo inteiro? Por que os pais são os únicos, se todos, inclusive eles, recebem influências do meio? Bato sempre nesta tecla: as crianças são responsabilidade de todos: uma criança mal formada, traz problemas para toda a sociedade e não só para o meio familiar. Criar crianças consumistas e com valores deturpados só traz benefícios para as empresas e transformar crianças em consumistas desde cedo, as influencia pelo resto da vida e ainda permite que o mercado as utilizem como ferramentas de influência de consumo dentro das famílias. ${ }^{36}$

As crianças brasileiras estão entre as que mais assistem à TV e acessam a internet no mundo. Somente em frente à televisão uma criança chega a passar um período superior a 5 horas diárias, conforme levantamento do IBOPE no ano de 2011. Isso significa dizer que as crianças estão expostas a campanhas publicitárias o dia todo, não somente as que são dirigidas diretamente a si, com também as dirigidas ao mundo adulto. O público jovem tornou-se alvo preferido do marketing, vez que o consumo infantil ultrapassa 15 bilhões de dólares no ano, e seu poder de in-

\footnotetext{
${ }^{36}$ FUTURO DO PRESENTE. Fim do abuso da \#publicidade infantil! Disponível em: <http://futurodopresente.com.br/blog/index.php/tag/resolucao-163/>. Acesso em: 10. Maio. 2015.
} 
fluência nas compras dos adultos é de aproximadamente 600 bilhões de dólares, números que realmente são de impressionar. ${ }^{37}$

O poder das crianças e adolescentes de influenciar nas decisões da família é grande, como expresso em valores econômicos acima.

Diante desse fato, ocorre além do crescimento de produtos e serviços infantis, um crescimento ainda mais significativo do marketing infantil, que acaba por abranger não apenas as estratégias para venda dos produtos infantis, mas também de venda dos produtos adultos, a partir da comunicação comercial com crianças. Conhecidos comerciais da televisão brasileira de produtos variados, como sucos, margarinas, maionese, eletrônicos, sabão em pó e outros utilizam de crianças, visando uma mensagem direta às crianças.

Dois exemplos são de uma famosa marca de sucos em pó, a qual sempre fez comerciais com destaque para as crianças, em rodas, sempre brincando e consumindo a bebida; e uma marca de sabão em pó dentre as mais conhecidas do país, com o conhecido comercial em que incentiva as crianças a brincarem, com cenas felizes, demonstrando a rotina infantil.

O exemplo mais marcante dos últimos anos, porém, é de uma marca de automóveis de origem francesa com atuação no Brasil, ao exibir em rede nacional o seu novo veículo lançamento fez um enredo no qual o filho, orgulhoso de seu pai ter adquirido o novo modelo, o faz estacionar em local estratégico em frente à escola, todos os dias, para que seus colegas possam ver a nova aquisição da família, sentindo-se realizado com a inveja produzida.

Essas são demonstrações de que, não apenas a publicidade de produtos infantis eclodiu e é forte, mas como produtos destinados até mesmo ao universo dos adultos ganham apelo ao público jovem, diante de sua intervenção nas decisões de consumo pela família como um todo.

Com a facilidade gerada pelos canais de televisão pagos e pelo acesso à internet houve um "boom" com relação às publicidades e produtos exclusivos dedicados aos jovens. Atualmente, as crianças brasileiras

${ }^{37}$ SANTOS, Andréia Mendes dos. Uma relação que dá peso: propaganda de alimentos direcionada para crianças, uma questão de saúde, direitos e educação. Publicidade e Proteção da Infância. Porto Alegre: Livraria do Advogado, 2014. p. 36. 
contam com uma média de seis canais exclusivos, com programação infantil 24 horas por dia, recheada de anúncios.

Vários são os dados que demonstram o consumismo exacerbado pelo mundo, principalmente pelas grandes potências.

Nos Estados Unidos, por exemplo, comum é o fato de a maioria das residências abrigarem em suas garagens grandes depósitos de coisas não utilizadas, muitas inclusive que nunca tiveram destinação por uma vez sequer. No Japão, existem verdadeiros cemitérios de eletrônicos, diante da evolução tecnológica extremamente rápida, ocasionando em produtos "ultrapassados" em curtíssimos espaços de tempo. ${ }^{38}$

O próprio Brasil, recentemente, atingiu um número de aparelhos celulares maior que os 200 milhões de habitantes, chegando à proporção de 137 celulares para cada 100 habitantes. ${ }^{39}$

Em muitos casos, o consumo exacerbado está ligado a emoções, sentimentos, e não a uma necessidade, como seria o coerente. Quando associado às emoções, o consumo tende a deixar um rastro de vazio sentimental, uma sensação de satisfação momentânea que em pouco tempo desaparece, restando a insatisfação. Hoje em dia, para algumas pessoas, comprar é sinônimo de felicidade e satisfação, principalmente se essas compras forem algo com uma marca renomada no mercado. Doce ilusão. Vale dizer que a publicidade possui um forte poder de influenciar, inclusive em valores essenciais, como escolhas de vida, definição de felicidade e de como medir o seu próprio valor. ${ }^{40}$

Se a publicidade e o consumo geram enorme influência no mundo adulto, o que não será capaz de fazer com o consumidor jovem, com nossas crianças e adolescentes que ainda estão em desenvolvimento, que carecem de experiência de vida e podem, na maioria das vezes, ser influenciados com maior facilidade. Com absoluta certeza o "estrago"

${ }^{38}$ KOVALICK, Roberto. Japão ganha com reciclagem de celulares. Disponível em: <http://g1.globo.com/jornal-nacional/noticia/2010/05/japao-ganha-comreciclagem-de-celulares.html>. Acesso em: 05.Out.2015.

39 TELECO. Estatísticas de celulares no Brasil. Disponível em: <http://www.teleco.com.br/ncel.asp>. Acesso em: 02.Jul.2015.

${ }^{40}$ SANTOS, Andréia Mendes dos. Uma relação que dá peso: propaganda de alimentos direcionada para crianças, uma questão de saúde, direitos e educação. Publicidade e Proteção da Infância. Porto Alegre: Livraria do Advogado, 2014. p. 40. 
pode e está sendo grande, pois as crianças são veementemente seduzidas a consumir.

As consequências pelo consumismo infantil decorrente da forte publicidade são as mais extensas. Um exemplo de peso é o caso da publicidade de alimentos, esses que são, na maioria esmagadora, alimentos processados, totalmente industrializados, com poucos nutrientes e ricos em gordura, sódio e açúcar. Dentro desse contexto, o Ministério da Saúde, aliado a outros Ministérios, colocou em prática o Plano Nacional de Doenças Crônicas Não Transmissíveis, o qual foi construído em parceria com instituições de ensino e pesquisa e diversas organizações não governamentais da área da saúde, associações médicas e de portadores de doenças crônicas, trabalhando juntos pela garantia à saúde de qualidade do consumidor. Logo em seu início, o Plano demonstra o agravamento de doenças crônicas não transmissíveis, tais como infarto, hipertensão arterial, acidente vascular cerebral, doenças respiratórias, dentre outras, que correspondem, juntas, à aproximadamente $70 \%$ das mortes no país. As causas dessas doenças podem ser resumidas no consumo de tabaco, bebidas alcoólicas e alimentos industrializados. ${ }^{41}$

Para as crianças e adolescentes, as consequências são mais graves, vez que acabam sofrendo, ainda no início de suas vidas e com seus corpos em desenvolvimento os abalos por tais práticas nada saudáveis. A obesidade infantil é o fruto do consumo exagerado de "fast-foods", "salgadinhos", chocolates, refrigerantes etc. Uma criança com esses hábitos, além de poder sofrer com a obesidade infantil, terá de arcar, em um futuro não distante, com muitas restrições à sua saúde, decorrentes do praticado enquanto jovem.

A criança não possui o necessário discernimento para entender o quão mal pode fazer a si consumindo alimentos indiscriminadamente. Pior, por vezes acaba consumindo em função de brinquedos e outros brindes do tipo que figuram em uma suposta promoção, como ocorre em grandes redes de fast-food, vide o Mc Lanche Feliz da rede Mc Donalds, caixas de cereais com brindes, refrigerantes realizando promoções com trocas e afins. Outro caso é o da empresa "Vigor", em parceria com a Disney. A marca de alimentos patrocinou a série Star Wars Rebels, que

${ }^{41}$ HENRIQUES, Isabella. Publicidade de alimentos e crianças: regulação no Brasil e no mundo. São Paulo: Saraiva, 2013. p. 58. 
foi exibida na televisão e desenvolveu uma ação mercadológica em múltiplas plataformas para as crianças. ${ }^{42}$

A erotização precoce é apenas mais um dos resultados infelizes ocasionados pela publicidade ao público jovem. As crianças incentivadas pela publicidade acabam pulando etapas importantes de seu desenvolvimento. Ao invés de brincar, elas passam a se preocupar em parecer mais velhas e atraentes, portando-se como adultas, com as pequenas meninas querendo utilizar de maquiagem, sapatos de salto e outras roupas e acessórios próprios de mulheres já formadas. Não foge da regra o caso do sexo masculino. ${ }^{43}$

Outra sequela grave é a violência e delinquência que resultam do incentivo ao consumo infantil aliado à educação de má qualidade e condições de vida indignas próprias da sociedade brasileira e outros países subdesenvolvidos. A publicidade contribui para a exclusão social, já que muitos não podem comprar aquilo que é anunciado.

Assim as crianças que não podem ter o que querem, muitas vezes, agem violentamente contra a família e contra a sociedade, buscam a qualquer preço o consumo daquilo que, em muitas vezes, nem precisam, alienados pelo desejo capitalista de consumir cada vez mais.

Diariamente é noticiada nos meios midiáticos, a prática de furtos e roubos por jovens, os quais procuram conseguir produtos "da moda", como smartphones e tênis de marca.

Vale mencionar, apenas a título exemplificativo inserido no contexto, o novo estilo musical surgido nas periferias paulistas, o conhecido "funk ostentação", que possui como mentores astros jovens, alguns inclusive com menos de 12 anos de idade. $\mathrm{O}$ estilo musical visa ao culto do consumo exacerbado, a valoração de bens materiais, como cordões de ouro, relógios importados, automóveis e motocicletas esportivos e de preço elevado. Essa modalidade de funk conquistou enorme sucesso em seu público alvo, os jovens. Uma ideologia de consumo cada vez mais implantada nessa classe etária.

\footnotetext{
${ }^{42}$ MIGALHAS ON LINE. Instituto Alana denúncia publicidade abusivas para crianças. Disponível em: <www.migalhas. com.br/Quentes/17,MI218698,31047-Instituto+Alana+denuncia+publicidades+a busivas+para +crianças>. Acesso em: 08. Maio. 2015.

${ }^{43}$ BESSA, Ana Cláudia. Principais consequências da publicidade infantil. Disponível em: <http://futurodopresente.com.br/ana/2010/06/principaisconsequencias-da-publicidade-infantil>. Acesso em: 31. Maio. 2015.
} 
O que existe atualmente é o culto ao consumo: as pessoas estão vivendo para consumir e não consumindo para viver. Além das consequências já apontadas acima, vale dizer do grande mal-estar causado nas famílias, vez que ao apresentar modelos de vida inalcançáveis, a publicidade passa a falsa ideia de famílias sempre perfeitas.

E quando os responsáveis dizem "não" às crianças, os conflitos são gerados. Muitos pais acabam cedendo à sede de consumo dos filhos por cansaço.

Mas o que esperar dessas hoje crianças em um futuro; como irão agir com relação a seus próprios filhos, suas vidas?

Muitos irão ter vidas vazias na parte sentimental por não atentarem para os verdadeiros valores da vida, para a família, amigos etc., vivendo, única e exclusivamente, como reféns do consumo.

Verifica-se até o presente momento que o aproveitamento da criança na sociedade de consumo pela publicidade a ela dirigida configura violação de seus direitos especialmente protegidos, mas que, ao mesmo tempo, a atividade publicitária está protegida por interesses constitucionais relevantes para a mesma sociedade de consumo. Tem-se um conflito e, a partir dele, problemas a serem respondidos pela pesquisa jurídica. ${ }^{44}$

\section{A REGULAMENTAÇÃO DA PUBLICIDADE NO BRASIL.}

O conceito de publicidade não é encontrado em nenhum diploma jurídico nacional, entretanto é passível no meio jurídico o fato da publicidade ser a atividade de comunicação que possui por finalidade informar e persuadir o consumidor sobre a existência de produtos e serviços, fixando marcas ou promover estilos de vida, para que simplesmente consuma.

O Ministro do Superior Tribunal de Justiça, Antônio Herman Benjamim, um dos que foram incumbidos da tarefa de regulamentar a publicidade no anteprojeto do Código de Defesa do Consumidor a define

\footnotetext{
${ }^{44}$ BRITTO, Igor Rodrigues. Infância e publicidade: proteção dos direitos fundamentais da criança na sociedade de consumo. 1. ed. Curitiba: CRV, 2010. p. 16.
} 
como "toda informação dirigida ao público com o objetivo de promover, direta ou indiretamente, uma atividade econômica". ${ }^{45}$

Apesar de serem utilizados como sinônimos na linguagem popular, os termos publicidade e propaganda não tratam da mesma atividade. Publicidade, como dito, visa a uma atividade econômica, possui cunho econômico, visa fomentar o consumo através da informação e persuasão do consumidor em potencial. ${ }^{46}$

Ao contrário, a propaganda não possui interesse econômico, seu objetivo é informar com várias finalidades, desde que não o consumo ${ }^{47}$. Um exemplo é a propaganda informando sobre a prevenção do câncer de mama, a qual constantemente aparece na TV, rádio e folhetos, visando apenas garantir e informar o cidadão sobre o quesito saúde. Enfim, são institutos diferentes e possuem regulamentações diferentes.

É possível citar, ainda, a diferença entre o termo merchandising, o qual deve ser utilizado corretamente para se referir às estratégias que as empresas de publicidade utilizam para expandir o produto, um conjunto de estratégias, como conhecer os clientes, suas necessidades, o que pretendem consumir etc. ${ }^{48}$ São ações utilizadas para a expansão mercadológica do produto, observando o mercado e suas exigências.

A liberdade de fazer publicidade possui proteção constitucional sob dois pilares: o primeiro como atividade econômica resguardada pela livre iniciativa, fundamento da ordem econômica (art. 170, caput e parágrafo único, CF), e livre concorrência. (art. 170, IV, CF); e pelo princípio da liberdade de expressão (arts. 5..$^{\circ}$, IX e 220, CF). ${ }^{49}$

Não há de se discutir a importância da publicidade para o atual mundo capitalista, menos ainda colocar em xeque sua proteção no mais

\footnotetext{
${ }^{45}$ BRITTO, Igor Rodrigues. Infância e publicidade: proteção dos direitos fundamentais da criança na sociedade de consumo. 1. ed. Curitiba: CRV, 2010. p. 36.

${ }^{46}$ SIGNIFICADOS. O que é Publicidade. Disponível em: <http://www.signi ficados.com.br/publicidade/>. Acesso em: 18.Set.2015.

47 DICIO. Significado de propaganda. Disponível em: <http://www.di cio.com.br/propaganda/>. Acesso em: 18.Set.2015.

${ }^{48}$ BALISTA. Kaue. Publicidade, marketing, propaganda, publicidade e merchandising. Qual a diferença? Disponível em: <http://kaueba lista.blogspot.com.br/2013/10/publicidade-propaganda-marketing-e.html>. Acesso em: 22.Set.2015.

${ }^{49}$ DIAS, Lucia Ancona Lopez de Magalhães. Publicidade e direito. 2. ed. São Paulo: Revista dos Tribunais, 2013. p. 33.
} 
alto âmbito jurídico nacional. Por outro lado, como dito no primeiro capítulo do presente trabalho, ao tratar da liberdade de expressão e suas restrições, não há direito absoluto, e mesmo aqueles fundamentais, gozando de proteção constitucional, podem sofrer limitações.

\subsection{SISTEMA MISTO.}

O Brasil adota, atualmente, assim como a maioria dos países do mundo, o conhecido sistema misto, através do qual o controle da publicidade ocorre de duas formas. Inicialmente, cumpre ressaltar a regulamentação privada, por meio da autorregulamentação da atividade pelos próprios agentes do mercado.

Para completar esse sistema misto, a outra vertente ocorre através do Estado, com a promulgação de normas e fiscalização, de forma que ambos os sistemas convivam de forma harmônica e pacífica.

Claro, em caso de conflito entre os sistemas privado e estatal, prevalece o último, vez que atua por meio de leis democraticamente promulgadas e sancionadas.

O sistema misto encontra diversas vantagens comparado a um sistema único, visto que acaba por existir uma espécie de harmonização entre ambas as vertentes, proporcionando, por um lado, soluções rápidas e menos burocráticas através dos próprios órgãos publicitários, e com uma fiscalização rígida e atuante do Estado naquilo que merece proteção específica por parte do mesmo.

\subsubsection{O CONTROLE AUTORREGULAMENTAR DA PUBLICIDADE}

O sistema privado ou autorregulamentar como é conhecido era o único vigente no país até a promulgação do Código de Defesa do Consumidor. Pode ser definido como o sistema regulatório no qual a própria indústria, ao invés de um órgão governamental, define e aplica as regras e 
parâmetros de conduta a serem observados pelos atuantes naquele mercado específico. ${ }^{50}$

O controle no Brasil ocorre através do Conselho Nacional de Autorregulamentação Publicitária, o CONAR, sociedade civil sem fins lucrativos, fundada por associações de anunciantes, agências de publicidade e veículos de comunicação, com a finalidade de executar e fiscalizar as suas normas éticas. Surgiu em um contexto no qual o governo buscava criar um sistema com censura prévia à publicidade, e para combater essa ameaça os próprios agentes publicitários criaram o seu sistema de regulamentação, zelando pela liberdade de expressão comercial e pela ética na publicidade, e ao mesmo tempo, como não poderia ser diferente, defendendo os interesses dos profissionais publicitários. ${ }^{51}$

O CONAR exerce sua atuação através do Código Brasileiro de Autorregulamentação Publicitária (CBARP), aprovado no ano de 1978 durante o III Congresso Brasileiro de Propaganda, anterior inclusive ao próprio CONAR, criado em 1980, com sede na cidade de São Paulo ${ }^{52}$.

Segundo o site oficial, o Código em destaque teve sua motivação no seguinte contexto:

O Código Brasileiro de Autorregulamentação Publicitária nasceu de uma ameaça ao setor: no final dos anos 70, o governo federal pensava em sancionar uma lei criando uma espécie de censura prévia à propaganda. Se a lei fosse implantada, nenhum anúncio poderia ser veiculado sem que antes recebesse um carimbo "De Acordo" ou algo parecido. A criação do departamento para controle da publicidade exigiria a contratação de algumas centenas de funcionários. As implicações burocráticas seriam inimagináveis ainda assim desprezíveis diante do retrocesso que tal controle representaria para um país que reconquistava a duras

${ }^{50}$ ALMEIDA, Candido Eduardo Mendes de. A autorregulamentação publicitária no Brasil. Rio de Janeiro: Pontifícia Universidade Católica do Rio de Janeiro, 2013. p. 13.

${ }^{51}$ DIAS, Lúcia Ancona Lopez de Magalhães. Publicidade e direito. 2. ed. São Paulo: Revista dos Tribunais, 2013. p. 39.

${ }^{52}$ CONAR. História. Disponível em: <http://www.conar.org.br/>. Acesso em: 02.Out.2015. 
penas seu direito à liberdade de expressão. Diante dessa ameaça, uma resposta inspirada: autorregulamentação, sintetizada num Código, que teria a função de zelar pela liberdade de expressão comercial e defender os interesses das partes envolvidas no mercado publicitário, inclusive os do consumidor. A idéia brotou naturalmente a partir do modelo inglês e ganhou força pelas mãos de alguns dos maiores nomes da publicidade brasileira. ${ }^{53}$

Incumbe ao CONAR, de acordo com o art. 5. ${ }^{\circ}$ do seu estatuto social, "zelar pela comunicação social, sob todas as formas de propaganda" e "funcionar como órgão judicante nos litígios éticos que tenham por objeto a indústria da propaganda ou questões a ela relativas". Passível de conclusão tratar-se da entidade privada que fiscaliza a publicidade no Brasil, utilizando como base o Código Brasileiro de Autorregulamentação Publicitária. Segundo informações oficiais da instituição em seu site oficial, "já instaurou mais de 7 mil processos éticos e promoveu um semnúmero de conciliações entre associados em conflito. Nunca foi desrespeitado pelos veículos de comunicação e, nas raras vezes em que foi questionado na Justiça, saiu-se vitorioso" 54 .

Considera-se um tribunal rápido e inimigo do excesso de formalismo, amoldando-se à evolução social.

Realmente é clara a conclusão de que o sistema privado possui suas imensas qualidades e significou grande evolução na história do país. Por meio do CONAR, é possível a reclamação de publicidades específicas que estejam sendo veiculadas, e pode ser feito de forma simplificada pela internet por qualquer cidadão, redigindo sua reclamação, de modo informal, a qual será avaliada e, caso necessário, transformada em denúncia pelo órgão interno competente.

Nas palavras de Fábio Ulhoa Coelho é confirmada essa visão, ao dizer que "a auto-regulação publicitária é, no Brasil, a mais interessan-

${ }^{53}$ BRASIL. Conselho Nacional de Autorregulamentação Publicitária. História. Disponível em: <www.conar.org.br〉. Acesso em: 31. Maio. 2015.

${ }^{54}$ CONAR. História. Disponível em: <http://www.conar.org.br/>. Acesso em: 02.Out.2015. 
te experiência de disciplina de atividade econômica por iniciativa dos próprios agentes nela envolvidos". ${ }^{55}$

Apesar de significar avanços, o sistema acima referido mostrase insuficiente e ineficaz. As suas normas não possuem caráter coercitivo de lei, acarretando imensos problemas na possibilidade de sanções a serem aplicadas pela instituição em seus julgamentos. Exemplificando: segundo o artigo 50 do CBARP, a penalidade máxima de competência do sistema privado é a recomendação de que a veiculação da publicidade em questão seja suspensa ou deixe de ser veiculada. Entretanto, como diz o próprio texto, é uma simples recomendação, sem caráter impositivo. ${ }^{56}$

A crítica mais profunda se volta ao fato de as decisões do CONAR só refletirem em seus signatários, não vinculando todos os agentes publicitários. Somente aqueles que se configuram na qualidade de associados é que são submetidos às suas decisões, e a contrário senso, os agentes que não fazem parte da ONG não estão sujeitos a nenhuma forma de controle pela autorregulamentação existente no Brasil.

Como explanado, as normas do CBARP aplicadas pelo CONAR não possuem caráter jurídico, força coercitiva e de imposição, são apenas normas éticas para orientação do mercado publicitário.

Desse modo, não há a configuração da outra vertente do símbolo jurídico da estátua da justiça, a espada, sem a qual não existe o alcance de determinações sem coerções. Revela-se apenas letra morta.

\subsubsection{CONTROLE ESTATAL DA PUBLICIDADE}

O controle por meio do Estado da publicidade surgiu, no Brasil, através do Código de Defesa do Consumidor, o qual regulamentou hipóteses de publicidade ilícitas (abusiva, enganosa e subliminar), matéria a qual foi feita referências apropriadas no primeiro capítulo deste, ao tratar das hipóteses de restrição da liberdade de expressão, sob a sua espécie de liberdade de publicidade. Inaugurou-se o sistema misto, conjugando ambos os sistemas a partir de então.

55 COELHO, Fábio Ulhoa. O empresário e os direitos do consumidor. São Paulo: Saraiva. 1994. p. 237.

${ }^{56}$ HENRIQUES, Isabella. Publicidade de alimentos e crianças: regulação no Brasil e no mundo. São Paulo: Saraiva, 2013. p. 52. 
A partir do ano de 1990, desse modo, a regulamentação da publicidade no Brasil acaba por seguir o modelo adotado por importantes democracias pelo mundo, o qual é desconcentrado e misto. Segundo as palavras de Antônio Herman de Vasconcellos e Benjamin, é desconcentrado por não haver uma centralização da regulamentação em um único órgão. Misto, por sua vez, devido à regulação efetuada tanto pelo Estado, tanto como pelos próprios agentes reguladores. ${ }^{57}$

Uma vez que o sancionamento ético-disciplinar do CONAR mostra-se insuficiente para o fim ao qual foi proposto, necessária a mão do Estado para regulamentar as hipóteses merecedoras de sua atenção, diante da vulnerabilidade do consumidor, parte hipossuficiente da relação de consumo.

Diante desse contexto, os sistemas privado e estatal se completam.

Apesar do Código Brasileiro de Autorregulamentação Publicitária não propiciar as ferramentas adequadas para que seja efetivamente respeitado, serve como material base para fundamentações de decisões jurisprudenciais.

Nesse sentido:

Propriedade industrial. Concorrência desleal. Propaganda comparativa. Possibilidade em tese, com reconhecimento todavia de abuso no caso concreto. Ré que não procura exaltar a superioridade de seu produto, mas que o equipara nominalmente à marca de titularidade da autora, com forma de afirmação da qualidade do primeiro. Tentativa, em princípio, de aproveitamento da imagem e prestígio alheios. Hipótese expressamente referida no Código Brasileiro de Autorregulamentação Publicitária como exemplo de propaganda comparativa indevida (art. 32, g). Tutela antecipada denegada em Primeiro Grau quanto à exclusão à referência à marca da autora, Bidim, no sítio eletrônico da ré. Decisão reformada. Presença de suficiente verossimilhança quanto ao direito da autora. Perigo

${ }^{57}$ BENJAMIN, Antonio Herman de Vasconcellos. [et al.] Código brasileiro de defesa do consumidor: comentado pelos autores do anteprojeto. Rio de Janeiro: Forense, 2001. p. 264. 
de dano igualmente justificado. Agravo de instrumento da autora provido - grifos não constante do original. ${ }^{58}$

Ademais, vale ressaltar que as normas do Código de Autorregulamentação Publicitária encontram-se em absoluta harmonia com o texto do Código de Defesa do Consumidor, que possui conteúdo sobre a matéria publicitária infinitamente mais rico que a legislação federal. São orientações que servem de fonte interpretativa subsidiária para o julgador, nos termos do art. 4. ${ }^{\circ}$ da Lei de Introdução às normas do Direito Brasileiro, e para a função legislativa. ${ }^{59}$

Finalmente, para encerrar o assunto sobre o sistema misto de regulamentação publicitária no Brasil, o controle estatal da publicidade é exercido pelos órgãos do Sistema Nacional de Defesa do Consumidor (SNDC) e pelos diversos órgãos federais, estaduais, municipais e as entidades civis de defesa do consumidor, como Ministério Público, o Procon e o próprio Poder Judiciário. ${ }^{60}$

\subsection{UMA RESOLUÇÃO POLÊMICA}

Diante do tema proposto para o trabalho, importante ressaltar normas específicas de regulamentação publicitária para o público abordado, qual seja, as crianças e adolescentes.

Depois de exarado de maneira sucinta o modelo utilizado em nosso país, cumpre salientar com certo nível de destaque, uma resolução que causou grande alvoroço no meio jurídico e publicitário quando de sua publicação: trata-se da conhecida Resolução n. ${ }^{\circ}$ 163, de 13 de março de

\footnotetext{
${ }^{58}$ BRASIL. Tribunal de Justiça do Estado de São Paulo. Agravo de instrumento n. ${ }^{\circ}$ 2062129-22.2014.8.26.0000, Relator Fabio Tabosa. Data de Julgamento: 07/07/2014. 2. ${ }^{\text {a }}$ Câmara Reservada de Direito Empresarial. Data de Publicação: 08/07/2014. Disponível em: <http://tj-sp.jusbrasil.com.br/jurispru dencia/126688461/agravo-de-instrumento-ai-20621292220148260000-sp-20621292220148260000>. Acesso em: 05. Jun. 2015.

${ }^{59}$ DIAS, Lúcia Ancona Lopez de Magalhães. Publicidade e direito. 2. ed. São Paulo: Revista dos Tribunais, 2013. p. 41.

${ }^{60}$ Ibidem. p. 43.
} 
2014 do Conselho Nacional dos Direitos da Criança e do Adolescente, o Conanda.

O Conanda é um órgão oficial, colegiado e permanente, de caráter deliberativo e composição paritária, com previsão no art. 88 do Estatuto da Criança e do Adolescente. Integra a estrutura básica da Secretaria de Direitos Humanos da Presidência da República. ${ }^{61}$

Criado pela Lei n. ${ }^{\circ} 8.242$ de 12 de outubro de 1991, ano seguinte ao ECA, é de sua competência elaborar normas gerais que coloquem em exercício os objetivos da política nacional de atendimento dos direitos da criança e do adolescente, fiscalizando todas as ações de execução, ressaltando, assim, seu dever de controle do Sistema de Garantias dos Direitos da Criança e do Adolescente no Brasil, do qual fazem parte toda a sociedade, inclusive o Estado. ${ }^{62}$

É a instância máxima, de caráter federal, em matéria de proteção da criança e adolescente, com a missão de fazer valer os direitos previstos no ECA, Constituição Federal e tratados internacionais dos quais o Brasil é signatário, e para exercer tal dever, pode editar Resoluções, as quais são atos normativos previstos no Art. 59 da Constituição Federal. Possui um sistema de funcionamento extremamente eficaz, visto que sua estrutura se concretiza por meio de uma rede de conselhos estaduais e municipais de direitos da criança e do adolescente que hoje somam mais de 5.100 conselhos em todo país, cobrindo em torno de $92 \%$ dos municípios brasileiros. ${ }^{63}$

Retornando ao centro do debate, no dia 13 de março de 2015 o Conanda publicou a sua resolução n. ${ }^{\circ}$ 163, fundamentada no Estatuto da Criança e Adolescente e no art.227 da Constituição Federal, responsável por estabelecer a teoria da proteção integral no âmbito nacional, regulamentando quais condutas se enquadram como publicidade abusiva para as

${ }^{61}$ BRASIL. Secretaria de Direitos Humanos. Conselho Nacional dos Direitos da Criança e do Adolescente (Conanda). Disponível em: <http://www.sdh .gov.br/sobre/participacao-social/conselho-nacional-dos-direitos-da-crianca-e-doadolescente-conanda>. Acesso em 10. Jul. 2015.

${ }^{62}$ ONG Criança e Consumo. Entenda a resolução que define a abusividade da publicidade infantil. Disponível em: <http://criancaeconsumo.org.br/noti cias/entenda-a-resolucao-que-define-a-abusividade-da-publicidade-infa ntil/>. Acesso em 10. Jul. 2015.

${ }^{63}$ BRASIL. Conselho Nacional dos Direitos da Criança e do Adolescente. Disponível em: <http://pndh3.com.br/geral/conanda-conselho-nacional-dosdireitos-da-crianca-e-do-adolescente/>. Acesso em 10. Jul. 2015. 
crianças, uma das espécies de publicidade ilícita previstas no Código de Defesa do Consumidor.

Em seu artigo $2 .^{\circ}$ caput e incisos, há a previsão das hipóteses consideradas abusivas para o público infantil:

Art. 2. ${ }^{\circ}$ Considera-se abusiva, em razão da política nacional de atendimento da criança e do adolescente, a prática do direcionamento de publicidade e de comunicação mercadológica à criança, com a intenção de persuadi-la para o consumo de qualquer produto ou serviço e utilizando-se, dentre outros, dos seguintes aspectos:

I - linguagem infantil, efeitos especiais e excesso de cores;

II - trilhas sonoras de músicas infantis ou cantadas por vozes de criança;

III - representação de criança;

IV - pessoas ou celebridades com apelo ao público infantil;

$\mathrm{V}$ - personagens ou apresentadores infantis;

VI - desenho animado ou de animação;

VII - bonecos ou similares;

VIII - promoção com distribuição de prêmios ou de brindes colecionáveis ou com apelos ao público infantil; e

IX - promoção com competições ou jogos com apelo ao público infantil. ${ }^{64}$

Como pode ser extraído da leitura do texto da norma acima, praticamente vedou-se qualquer publicidade destinada às crianças, e realmente foi o que ocorreu no país em um primeiro momento. Logo após a sua publicação, desapareceram da TV e outros meios de comunicação em massa as publicidades destinadas a esse nicho, e consequentemente, como efeito "dominó", o mesmo destino foi dado aos tradicionais programas infantis na rede aberta de televisão, com a exibição de desenhos matinais. Grande foi a repercussão e discussão, algo perfeitamente aceitável diante

${ }^{64}$ BRASIL. Conselho Nacional da Criança e Adolescente. Resolução 163 de 03 de março de 2014. Disponível em: http://www.m pba.mp.br/atuacao/infancia/publicidadeeconsumo/conanda/resolucao_163_conan da.pdf>. Acesso em: 14.Jul.2015. 
das consequências tamanhas geradas por essa resolução, com impactos intensos na economia e em estratégias de marketing.

Grandes empresas, de renome internacional inclusive, foram partes ativas e passivas de ações judiciais fundadas na resolução 163 do Conanda.

O caso mais emblemático é configurado pela multinacional Arcos Dourados, representante da rede McDonald's na América Latina, autora de uma ação ${ }^{65}$ pleiteando a anulação de uma sanção econômica aplicada contra si, com valor superior aos 3 milhões de reais, aplicada pela Fundação de Proteção e Defesa do Consumidor do Estado de São Paulo - Procon, em função de suposta publicidade abusiva na venda do kit conhecido como "Mc Lanche Feliz", o qual conjuga a venda de um lanche em embalagens atrativas para o público infantil, acompanhado de um brinde, na maioria das vezes brinquedos relacionados a personagens populares nessa classe da sociedade, violando claramente a norma do inciso VIII do art. 2. ${ }^{\circ}$ da Resolução supracitada.

$\mathrm{O}$ pedido do autor foi julgado procedente no primeiro grau de jurisdição, e em recurso de apelação julgado recentemente pelo TJ-SP, 29 de junho de 2015, na 5. ${ }^{\text {a }}$ Câmara de Direito Público do Tribunal de Justiça do Estado de São Paulo, com relator o desembargador Firmino Magnani Filho, mantida foi a decisão. Vale, pela sua importância de criar precedentes de aplicação e interpretação da resolução do Conanda, a necessidade de citação:

MULTA ADMINISTRATIVA - Sanção cominada pelo PROCON em razão de publicidade considerada abusiva - Veiculação da comercialização de lanches e brinquedos atrelados a ocasiões de convívio - Kit "Mc Lanche Feliz" - Abusividade não verificada, não comportando interpretação literal o disposto na Resolução n. ${ }^{\circ}$ 163/2014 do CONANDA Responsabilidade familiar pela educação dos filhos que não pode ser absorvida pelo Estado em todas as hipóteses, em paternalismo injustificável -

65 BRASIL. Tribunal de Justiça do Estado de São Paulo. Apelação ${ }^{\circ}$ 00182341720138260053. 5 $5^{\text {a }}$ Câmara de Direito Público. Data de Publicação: 30/06/2015. Disponível em: <http://tj-sp.jusbrasil.com.br/jurisprudencia/20 4200291/apelacao-apl-182341720138260053-sp-0018234-1720138260053>.

Acesso em: 14.Jul.2015. 
Precedente jurisprudencial - Apelação do PROCON não provida. ${ }^{66}$

No teor do acórdão, ainda é possível encontrar as justificativas para o julgamento favorecendo a rede McDonald's:

Neste aspecto, não vislumbro prática abusiva da vendedora de sanduíches na hipótese dos autos.

Tomemos estas quatro premissas:

a) A sociedade brasileira se rege pelo modelo capitalista, e as consequências dessa opção econômica e cultural hão de ser assumidas;

b) Cabe à família, notadamente aos pais ou ao responsável legal, o poder-dever da boa educação dos filhos, inclusive o ônus de reprimi-los nos apelos inconvenientes ao seu bem estar social, físico e mental;

c) Crianças bem educadas no berço, por força do afeto e da autoridade dos pais ou responsável, saberão resistir aos apelos consumistas;

d) Não deve o Estado, de modo paternalista, sobrepor-se às obrigações primárias da família, sobretudo quando incitado pelo barulho muito atual, mas com um quê autoritário, da militância "ongueira", sob pena do esgarçamento da legitimidade de seus atos de império. ${ }^{67}$

Apesar da enorme importância verificada na intenção do Conselho Nacional dos Direitos da Criança e do Adolescente ao regulamentar a publicidade abusiva para o público infantil, algo que diante da omissão legislativa federal é perfeitamente enquadrado em sua competência, os tribunais não têm seguido à risca a determinação, alegando que não é possível uma interpretação literal de suas normas.

${ }^{66}$ BRASIL. Tribunal de Justiça do Estado de São Paulo. Apelação n. ${ }^{\circ}$ 0018234-17.2013.8.26.0053. Relator Fermino Magnani Filho. Data de Julgamento: 29/06/2015. 5. ${ }^{a}$ Câmara de Direito Público. Data de Publicação: 30/06/2015. Disponível em: <http://tj-sp.jusbrasil.com.br/jurisprudencia/204200 291/apelacao-apl-182341 720138260053-sp-0018234-1720138260053 >. Acesso em: 15. Jul. 2015.

${ }^{67}$ Ibidem. 
Estão criando um valor extremamente diminuto para a resolução, quiçá valor algum, perfazendo as palavras em letra morta.

Acabam, novamente, por incumbir toda a responsabilidade apenas à família, mas esquecem da prioridade absoluta determinada no artigo 227 da Constituição Federal, o mesmo que determina não só a responsabilidade da família, mas também da sociedade e do Estado.

Com toda certeza trata-se de uma luta desigual, de um lado agências publicitárias com profissionais altamente especializados em tentar quebrar essa barreira de proteção familiar, munidos ainda de cifras astronômicas para a conclusão da tarefa. De outro lado, os pais, reféns da sua falta de tempo diária, da insegurança das ruas, da internet, TV etc. Logicamente um Estado intervencionista ao extremo não é o ideal, mas em certos casos necessária se faz, principalmente em casos de defesa da parte hipossuficiente, tal intervenção.

\subsection{PROJETOS DE LEI.}

Atualmente mais de 20 projetos de lei relacionados ao tema publicidade infantil estão em tramitação no Congresso Nacional, em ambas as casas. Possuem propostas variadas, entre elas vedar a comercialização de lanches acompanhados de brinquedos e instituição de regras para a veiculação de publicidade de alimentos obesogênicos. Porém o mais debatido e comentado atualmente é o Projeto de Lei n. ${ }^{\circ} 5.921 / 2001^{68}$, proposto pelo deputado Luiz Carlos Hauly em 12 de dezembro de 2001, que visa proibir de vez a publicidade dirigida ao público infantil e regulamentar a destinada aos adolescentes.

Há quase uma década e meia o projeto está em discussão, sendo possuidor de uma longa trajetória, a qual ainda se encontra sem uma solução rápida à vista. Originalmente, o objetivo se delimitava em alterar o artigo 37 do Código de Defesa do Consumidor, acrescentando um parágrafo, de modo a vedar totalmente a publicidade destinada à venda de produtos infantis.

${ }^{68}$ CRIANÇA E CONSUMO. Legislação. Projetos de Lei. Disponível em: $<$ http://criancaeconsumo.org.br/advocacy/legislacao-nacional/>. Acesso em: 07.Jul.2015. 
Por outro lado, nessa longínqua história de vida, já adolescente por sinal, o projeto possui vários textos substitutivos, passou pela Comissão de Defesa do Consumidor; Comissão de Desenvolvimento Econômico, Indústria e Comércio; Comissão de Ciência e Tecnologia, Comunicação e Informática; Comissão de Ciência e Tecnologia, Comunicação e Informática; Audiência Pública realizada em 3 de julho de 2012, na Câmara dos Deputados, com a presença de diversos órgãos representativos de ambas as esferas de interesse etc ${ }^{69}$.

Atualmente o projeto segue aguardando parecer do Relator na Comissão de Constituição e Justiça e de Cidadania ${ }^{70}$, com o texto substitutivo da deputada Maria do Carmo Lara, que transformou a ideia inicial de modificar o CDC para a realização de uma lei federal específica para regulamentação, contendo 7 artigos, fundamentando ser o Código de Defesa do Consumidor uma lei geral que não merece especificidades tamanhas.

A pressão de diversas entidades ligadas à proteção das crianças e adolescentes cresce a cada dia; divulgações favoráveis à aprovação do projeto ocorrem por todo o país, principalmente pela internet. Desde ONGs até associações de mães estão nessa luta constante.

De outro lado, o interesse de uma indústria milionária e influente, com o poder de fazer os vários projetos de lei sobre o tema se arrastarem por anos em debates pelas comissões do Congresso.

\section{DIREITO COMPARADO}

Através do Direito Comparado uma visão crítica sobre a ordem jurídica de um determinado país surge, utilizando como base de sustentação as diferenças e semelhanças encontradas das comparações internacionais.

Trata-se do polo antagônico ao isolacionismo, de modo que, ao permitir uma intercomunicação das soluções ora apresentadas pelas nações mundo a fora, cada qual com seu particular cultural, social e econô-

${ }^{69}$ CÂMARA DOS DEPUTADOS. Projeto de Lei 5921/2001. Disponível em: $<$ http://www.camara.gov.br/proposicoesWeb/fichadetramitacao?idProposicao=4 3201>. Acesso em 08.Jul.2015.

${ }^{70}$ Ibidem. 
mico, várias consequências em potencial são passíveis de ocorrer, entre elas, e talvez mais importante, a influência exercida na política legislativa.

Em um contexto de publicidade, consumismo e proteção da criança e adolescente, temas que perfazem o cotidiano da maioria das nações e estão previstos em tratados internacionais, e que, ainda, cresceram em época de globalização, impossível não mencionar a regulamentação adotada por alguns países.

\subsection{PORTUGAL.}

O país possui um debate assíduo acerca do tema publicidade infantil. Diferentemente do que ocorre no Brasil, apesar de também ser adotado um sistema misto de regulamentação, há em Portugal um diploma legal específico responsável por reger o tema em questão, o Código da Publicidade (DL 330/90), o qual possui 43 artigos em seu conteúdo. ${ }^{71}$

Apesar de que, em síntese, a legislação portuguesa procura estabelecer normas com certo teor de equilíbrio em relação a garantir a proteção das crianças e ao mesmo tempo a liberdade de iniciativa, muitas são as hipóteses de restrição, desde o tempo gasto com publicidade nos meios midiáticos até a vedação de ditos "programas-publicidade", os quais procuram entreter objetivando exclusivamente a publicidade de produtos e serviços dentro do próprio programa.

Outra restrição importante está atrelada ao fato de menores de idade participarem de peças publicitárias somente se houver uma relação direta entre eles e o produto anunciado.

Mas nada é mais eficaz que a norma do artigo $14 .^{\circ}$ do referido Código de Publicidade, a qual preceitua:

1 - A publicidade especialmente dirigida a menores deve ter sempre em conta a sua vulnerabilidade psicológica, abstendo-se, nomeadamente, de:

${ }^{71}$ FROTA, Mário. A publicidade infanto-juvenil: perversões e perspectivas. Curitiba: Juruá, 2006. p. 75. 
a) Incitar directamente os menores, explorando a sua inexperiência ou credulidade, a adquirir um determinado bem ou serviço;

b) Incitar directamente os menores a persuadirem os seus pais ou terceiros a comprarem os produtos ou serviços em questão;

c) Conter elementos susceptíveis de fazerem perigar a sua integridade física ou moral, bem como a sua saúde ou segurança, nomeadamente através de cenas de pornografia ou do incitamento à violência;

d) Explorar a confiança especial que os menores depositam nos seus pais, tutores ou professores.

2 - Os menores só podem ser intervenientes principais nas mensagens publicitárias em que se verifique existir uma relação directa entre eles e o produto ou serviço veiculado. ${ }^{72}$

Inegável que ao reconhecer no próprio texto legal a vulnerabilidade psicológica dos menores e realizar vedações amplas desse modo fundamentadas, Portugal acabou por ter uma legislação eficaz e moderna, ao menos em teoria.

Em suma, a publicidade dirigida ao público infantil português existe, mas com toda certeza conta com restrições mais abrangentes que no Brasil, o que se deve basicamente ao fato da existência de uma codificação específica para o tema e a preocupação com a hipossuficiência dos ditos menores.

\subsection{INGLATERRA}

País detentor de uma das maiores economias mundiais, altamente desenvolvido e com altos índices de consumo, a Inglaterra adota apenas o sistema de autorregulamentação, não existindo disposições emanadas do Estado.

Apesar das críticas próprias existentes a tal sistema, as quais já foram abordadas, neste país há peculiaridades que resultam em um resul-

72 PORTUGAL. Código Da Publicidade. Decreto-Lei n. ${ }^{\circ}$ 330/90 de 23 de Outubro. Disponível em: <http://www.bocc.ubi.pt/pag/estado-portugues-codigopublicidade.html>. Acesso em: 15. Jul. 2015. 
tado final mais seguro e eficaz, visto que vários são os órgãos reguladores, existindo alguns cujo financiamento é exclusivo por parte do governo.

Por muitos é apontado como o sistema a ser seguido, eleito pelos defensores mais rigorosos de uma maior regulamentação do tema como um modelo.

O tema encontra-se regulamentado no ATC Code of Advertising Standards and Practice, de 1998, existindo um apêndice ou espécie de capítulo no qual estão contidas as normas para proteção do público infantil. $^{73}$

No documento mencionado, os ingleses acabam reconhecendo o estado de vulnerabilidade das crianças, principalmente com fundamentação no fato de não possuírem a devida maturidade para a distinção entre realidade e fantasia, ocasião em que a publicidade pode gerar sérios danos.

Nesse sentido, a Inglaterra acaba por impor restrições específicas, como a proibição de mascotes para anúncios de alimentos; vedação de qualquer espécie de publicidade para o nicho infantil feitas por telefone, correio e internet; e ainda o fato de que nenhuma campanha publicitária de produtos ou serviços pode ter como tática levar as crianças a menosprezo ou inferiorização por não consumir o oferecido. ${ }^{74}$

\subsection{ALEMANHA}

No que diz respeito à publicidade e sua regulamentação, a Alemanha adotou um sistema misto, com algumas semelhanças ao Brasil, mas não deixa de lado as suas peculiaridades relevantes. $O$ primeiro fato a ser citado é que cada estado possui a sua competência própria para regulamentar a publicidade, de acordo com seus costumes e necessidades locais. Por outro lado, entre os estados membros há compromissos assinados em tratados interestaduais que procuram uniformizar o que há de

${ }^{73}$ PORTO, Renato. Publicidade digital: proteção da criança e do adolescente. São Paulo: Saraiva, 2014. p. 165.

74 INSTITUTO ALANA. Criança e Consumo. Disponível em: $<$ http://criancaeconsumo.org.br/ internacional/inglaterra/>. Acesso em: 16. Jul. 2015. 
mais relevante, não existindo grandes divergências a serem apontadas entre um e outro. ${ }^{75}$

O Conselho Alemão de Normas de Publicidade é o órgão responsável pela autorregulamentação, redigindo regras as quais os seus membros ficam comprometidos a respeitar. Uma das normas, por exemplo, restringe a publicidade de alimentos e bebidas de modo a seduzir as crianças.

A República Federal da Alemanha, ou simplesmente Alemanha, encerrando, possui um sistema moderno, o qual recebeu importantes reformas e está de acordo com a política de proteção da criança e do adolescente. Vale ressaltar que, dentre as inovações, está a proibição de os programas infantis possuírem intervalos comerciais, devendo ser transmitidos sem qualquer interrupção. Talvez a principal evolução esteja no limite máximo de 20 minutos diários para publicidade infantil destinados a cada emissora, os quais ainda somente podem ser utilizados após as 20 horas, momento até o qual é absolutamente proibida qualquer publicidade na TV com destino a esse público. ${ }^{76}$

\subsection{ESTADOS UNIDOS DA AMÉRICA}

Obviamente a maior economia mundial, o país pautado pelo consumo, planejado para o consumo e, claro, com as maiores variedades de produtos para todos os fins imagináveis não poderia ficar de fora. Os EUA constituem o berço do capitalismo moderno, de marcas de renome internacional como Coca-Cola, McDonald's, Nike, Apple, Microsoft, Google etc. É o maior importador do mundo e terceiro maior exportador, e produz mais de $20 \%$ do PIB mundial. Os números impressionam. O país conta com apenas $5 \%$ da população mundial, mas consome mais de $25 \%$ da energia, e emite quase $40 \%$ dos gases responsáveis pelo efeito estufa. $^{77}$

\footnotetext{
${ }^{75}$ HENRIQUES, Isabella. Publicidade de alimentos e crianças: a regulamentação no Brasil e no mundo. São Paulo: Saraiva, 2013. p. 129.

${ }^{76}$ PORTO, Renato. Publicidade digital: proteção da criança e do adolescente. São Paulo: Saraiva, 2014. p. 165.

${ }^{77}$ GUSMÃO, Ronaldo. O insustentável consumo norte americano. Disponível em: <http://www.techoje.com.br/site/techoje/categoria/detalheartigo/11>. Acesso em: 21. Jul. 2015.
} 
Além de suas marcas e produtos mundialmente conhecidos e consumidos, os Estados Unidos possuem a maior indústria de entretenimento mundial, inclusive para crianças, através de seus personagens animados, super-heróis e afins, responsáveis por atrair a atenção dos jovens e cativá-los.

É adotado um sistema misto de regulamentação publicitária no país, o qual é dividido no controle estatal através da Lei de Programação Televisiva Dirigida ao Público Infantil, de 1990; e na outra vertente, através da organização CARU (Unidade de Revisão da Publicidade para Crianças, na tradução da sigla para o português), responsável por fiscalizar o ideal cumprimento das suas normas autorregulatórias e da própria legislação. ${ }^{78}$

Apesar de uma lei específica para o assunto, o que poderia significar um avanço em relação a vários países que não possuem em seu ordenamento jurídico um diploma legal semelhante, o sistema americano mostra-se bastante falho e praticamente sem restrição alguma. A norma presente na lei supracitada, que representa a maior imposição em face da proteção de crianças, estabelece um limite entre 10 e 12 minutos de publicidade destinada diretamente a esse público por hora. Em uma conta rápida conclui-se que um canal de televisão, por exemplo, pode transmitir quase 5 horas diárias somente de publicidade destinada a este nicho de consumidores. $^{79}$

Desde a década de 1990, existiram várias tentativas de uma restrição maior por parte do Estado em função da proteção dos jovens americanos, todas absolutamente barradas, com poucas conquistas apenas no campo da autorregulamentação, quase que insignificantes.

Nesse sentido, assevera Isabella Henriques:

Várias tentativas, provenientes de diferentes setores, no sentido de promulgar uma legislação ou regulamentação estatal enfrentaram forte resistência. Uma série de fatores pode ajudar a explicar esta resistência à mudança. Em primeiro lugar, a cultura

\footnotetext{
${ }^{78}$ HENRIQUES, Isabella. Publicidade de alimentos e crianças: a regulamentação no Brasil e no mundo. São Paulo: Saraiva, 2013. p. 109.

79 INSTITUTO ALANA. Criança e consumo. Disponível em: <http://criancaeconsumo.org.br/ internacional/estados-unidos/>. Acesso em: 23. Jul. 2015.
} 
dos Estados Unidos enfatiza fortemente tanto a responsabilidade individual (neste caso, a proteção dos filhos pelos pais) como a livre-iniciativa. Esta cultura é apoiada pela proteção constitucional à liberdade de expressão, que não parece ser ativamente levada em conta neste debate, mas parece exercer algum tipo de influência. ${ }^{80}$

Claro que o resultado não poderia ser outro senão uma avalanche de publicidade no país, a qual sustenta todo o seu sistema e suas indústrias multinacionais responsáveis pela implantação da cultura do consumo. Os EUA somente conseguem ser a maior economia mundial pelo seu próprio consumo interno ser gigantesco, e para a cultura dos exageros nada mais eficaz que publicidade em exagero.

A mãe de uma menina de 7 anos de idade e residente nos Estados Unidos assim descreveu o seu pensamento sobre a publicidade exibida no país:

A publicidade exibida nos canais infantis me preocupa um pouco, pois em razão das diferenças culturais, não sou muito fã do consumismo sem limites. Acho que, de certa forma, essas propagandas incentivam o pensamento de que tudo é descartável e reforça a cultura do desperdício, da reposição e da oferta quase ilimitada. ${ }^{81}$

O problema se perfaz na forte influência que exerce em outros países, na exportação de sua cultura. No Brasil, a título exemplificativo, quase tudo é comparado aos Estados Unidos, principalmente quando o tema é consumo de produtos e serviços, sempre menosprezando o nacional e valorizando o norte americano. Para muitos brasileiros o sonho de vida, de possível realização é consumir como um cidadão americano.

${ }^{80}$ HENRIQUES, Isabella. Publicidade de alimentos e crianças: a regulamentação no Brasil e no mundo. São Paulo: Saraiva, 2013. p. 109.

81 CAMPELLO, Rachel. No mundo da publicidade infantil. Organização ABAP. Disponível em: <http://www.abapnacional.com.br/pdfs/nomundodapubli cidadeinfantil.pdf $>$. Acesso em: 23. Jul. 2015. 
Os valores estão sendo perdidos. O consumo deve fazer parte da vida, e não se tornar objetivo de vida.

\subsection{CHILE}

O Chile é um dos países mais respeitados em nossa região geográfica, possui significantes avanços em termos de direitos sociais e educação quando comparado a seus vizinhos. É detentor do IDH mais elevado da América do Sul, de 0,822 no ano de 2013, considerado "Muito Alto" na classificação oficial, acima de países como Portugal e Hungria, e com uma diferença significativa quando comparado ao Brasil. ${ }^{82}$

Adota, assim como a maioria dos países, um sistema misto de regulamentação publicitária. O órgão responsável pela autorregulamentação é o Consejo de Autorregulación y Ética Publicitaria, o qual utiliza da mesma sigla do órgão brasileiro, CONAR. Exerce a sua função através do Código de Ética Publicitária, o qual apesar de não ser específico para a regulamentação destinada ao público infantil, possui em seu corpo algumas normas que, em síntese, declaram a inexperiência das crianças, além de vedar a publicidade que explore a ingenuidade, imaturidade, inexperiência ou credulidade, características naturais de quem está em fase de formação. ${ }^{83}$

Logicamente que sofre com os males já apontados de um sistema simples de autorregulamentação, assim como ocorre com o Brasil, e diferentemente da Inglaterra.

O debate sobre publicidade infantil no país é recente, e somente no ano de 2012 foi sancionada a Lei n. 20.606 pelo presidente Sebastián Piñera, destinada basicamente à vedação de qualquer publicidade destinada a menores de 14 anos com referências a alimentos não saudáveis. Ficou a cargo do Ministério da Saúde chileno definir quais são os alimentos e bebidas que se enquadram na regulamentação legal, através de vários

82 Ranking IDH Global 2013. Disponível em: <http://www.pnud.org .br/atlas/ranking/Ranking-IDH-Global-2013.aspx>. Acesso em: 23. Jul. 2015.

${ }^{83}$ SILVA, Rosane Leal da; MARQUEZAN, Bibiana Simões. A publicidade online: desafios para proteger crianças e adolescentes da publicidade abusiva na Internet. Disponível em: <http://www.ambito-juridico.com.br/site/in dex.php?n_link=revista_artigos_leitura\&artigo_id=9675>. Acesso em: 23. Jul. 2015. 
critérios previamente definidos. Com essa norma, exemplificativamente, os brindes infantis na compra de lanches são permanentemente vedados no país.

O objetivo da lei é combater a obesidade infantil e outras doenças crônicas relacionadas à má alimentação que estão crescendo desenfreadamente pelo mundo e assolando os cidadãos desde os primeiros anos de vida. A restrição da publicidade assim, foi, nesse país, uma das muitas ferramentas utilizadas para impor uma política de vida mais saudável. ${ }^{84}$

\subsection{OUTRAS DISPOSIÇÕES PELO MUNDO}

Seria absolutamente viável a realização de um trabalho de pesquisa somente com o direito comparado envolvendo o tema em questão, diante do conteúdo disponível. Não é o objetivo atual um aprofundamento sobre a regulamentação dos vários países pelo mundo, mas sim utilizar de uma síntese sobre cada sistema adotado e suas principais peculiaridades para que através desse presente estudo se chegue à conclusão do melhor para o Brasil.

Diante dessa tarefa, alguns países foram os escolhidos para figurarem nesse capítulo. Entretanto há muitas outras peculiaridades mundo afora, muitas regulamentações que podem influenciar. A Argentina, por exemplo, adota um sistema extremamente parecido com o Brasil, o que chega a dar a impressão de terem sido pensados em conjunto. $\mathrm{Na}$ Irlanda do Norte, por sua vez, país que detém um dos códigos de autorregulamentação mais avançados no mundo, as celebridades que mantêm programas de TV infantis não podem comercializar produtos destinados às crianças oriundos de tais programações. ${ }^{85}$

O Canadá adota um sistema moderno de autorregulamentação publicitária, e entre as suas principais normas há o estabelecimento de

${ }^{84}$ CONSUMO E INFÂNCIA. Chile aprova lei que proíbe publicidade de alimentos não saudáveis para menores de 14 anos. Blog Consumismo e Infância. Disponível em: <http://www.consumismoeinfancia.com/15/05/2012/ chileaprova-lei-que-proibe-publicidade-de-alimentos-nao-saudaveis-para-menores-de14-anos/>. Acesso em: 23. Jul. 2015.

${ }^{85}$ ARAGÃO NETO, Dário. Direitos humanos e a publicidade infantil na Argentina e no Brasil. Disponível em: <http://coral.ufsm.br/congresso direito/anais/2013/6-12.pdf>. Acesso em: 23. Jul. 2015. 
não ser possível haver publicidade com bonecos, pessoas ou personagens conhecidos, exceto para campanhas sobre boa alimentação, segurança, educação, cultura, saúde, meio ambiente, etc. ${ }^{86}$

Enfim, muitos são os exemplos e divergências dentro do cenário internacional. Cada país com um sistema próprio, enraizado por sua cultura, como é possível observar nos Estados Unidos e Inglaterra de forma cristalina. Todos possuem seus pontos positivos e negativos, em maior ou menor expressão.

\section{CONSIDERAÇÕES FINAIS}

No presente trabalho, foi estabelecido o grande conflito envolvendo direitos constitucionais presentes na discussão abordada, seja a proteção integral da criança e a liberdade de expressão, em sua modalidade liberdade de publicidade. É possível citar outros direitos em ambos os polos, como a proteção do consumidor e a livre iniciativa, os quais servem de sustentáculo para cada vertente.

Canotilho ${ }^{87}$ preceitua que a tarefa do intérprete da constituição é de considerá-la em sua globalidade e procurar a busca pela harmonização entre as tensões existentes.

Os conflitos devem ser solucionados de modo racional e, no caso em questão, a solução deve ser pautada com a unicidade da Constituição. Apesar de ser uma tarefa árdua, torna-se necessária, e sempre será quando surgir algum modo de embate, de tensão entre os princípios constitucionais, os quais serão sopesados no caso concreto, sem uma regra absoluta de hierarquia.

Robert Alexy ${ }^{88}$ defende a ideia do sopesamento de direitos como forma de resolução de conflitos em cada caso concreto, observando as suas peculiaridades, pensamento esse expresso durante a parte inicial do trabalho, e o qual será a base para a conclusão.

86 INSTITUTO ALANA. Criança e consumo. Disponível em: <http ://criancaeconsumo.org.br/internacional/canada/>. Acesso em: 23. Jul. 2015.

${ }^{87}$ CANOTILHO, José Joaquim Gomes. Direito constitucional e teoria da constituição. 8. ed. São Paulo: Almedina Brasil, 2004. p. 226.

${ }^{88}$ ALEXY, Robert. Teoria dos direitos fundamentais. Trad. Virgílio Afonso da Silva. São Paulo: Malheiros, 2008. p. 128. 
Ficou claramente expresso o fato de que o sistema atual adotado pelo Brasil é falho, principalmente pela falta de lei específica sobre regulamentação da publicidade em geral, e, em especial, para as crianças e adolescentes. O Código de Defesa do Consumidor resultou em um avanço sem precedentes como defesa de uma parte hipossuficiente na relação de consumo, mas ainda não é o bastante para solucionar o conflito.

Deve ser mencionado que apesar de ambos os direitos gozarem de proteção constitucional e serem fundamentais, além de estarem previstos por tratados internacionais mundo afora, alguns dos quais o Brasil é signatário, no caso concreto o direito de liberdade de publicidade é exercido na maioria esmagadora das vezes por pessoas jurídicas, empresas que se dedicam ao exercício de persuadir pessoas ao consumo. De outro lado, porém, a proteção integral da criança e do adolescente está voltada para pessoas físicas, essas que estão em um estágio particular do desenvolvimento humano que requer maiores cuidados diante da vulnerabilidade que lhes é inerente. A própria constituição utiliza da expressão "prioridade" para assegurar tais indivíduos, declarando, por fim, a responsabilidade da família, da sociedade e do Estado.

Não seria justo priorizar um direito voltado para indústrias que são, muitas vezes, grandes multinacionais com um poder econômico sem igual, empregando cifras imensuráveis e utilizando de profissionais preparados para utilizar de todo o arsenal disponível para persuadir um público vulnerável. Mas, por outro lado, acabar com esse mercado de maneira absoluta não estaria em acordo com a ideia de sopesamento de direitos, de uma solução equilibrada.

Desse modo, após todo o material estudado, os diversos livros, artigos, jurisprudência e breve busca em direito comparado, foi possível concluir que o ideal seria a existência de uma lei de âmbito federal para regulamentar a publicidade infantil, a qual não existe atualmente e claramente faz com que o Brasil cometa deslizes sobre o preceituado em sua própria constituição. O legislador nacional, aliás, há mais de uma década vem postergando essa discussão, talvez influenciado pelo poder da grande indústria publicitária que busca barrar qualquer projeto sobre o tema de restrição da publicidade, acarretando em um Congresso Nacional repleto de projetos, os quais não possuem prosseguimento satisfatório.

Talvez a proposta mais interessante seja a de veicular a publicidade de produtos voltados ao público infantil para os seus responsáveis, ideia levantada por muitas entidades defensoras das crianças e adolescen- 
tes, não utilizando de elementos que atraiam a atenção desse público capaz de persuadi-los diretamente. Os próprios responsáveis pela sua educação receberiam o material publicitário de forma direta, sem a influência de seus pequenos. Nessa hipótese, seriam os pais ou outros incumbidos do cuidado de educar que iriam utilizar o filtro da publicidade e consumo, permanecendo as crianças alheias da relação publicitária, vez que não possuem um estágio de desenvolvimento capaz de serem público alvo de publicidade sem que isso não lhes acarrete consequências danosas, como explanado no corpo do presente trabalho.

Ao público adolescente, pelo fato de serem detentores de um desenvolvimento que os torna um pouco menos vulneráveis que as crianças, as quais até certa idade não conseguem, inclusive, distinguir fantasia de realidade, o exemplo utilizado pela Alemanha seria o melhor, impondo um limite temporal de publicidade diária direcionada a esse nicho. Apesar do maior desenvolvimento este ainda é incompleto, e diante dessa situação não seria interessante permitir sem restrições as campanhas publicitarias com destino específico aos adolescentes. O país da União Europeia tem conseguido resultados satisfatórios e recebido reconhecimento internacional por utilizar de um limite máximo diário de tempo em que seja possível veicular publicidade em suas emissoras.

Enfim, um tema de grandes proporções e abrangência multidisciplinar, carente de atenção do legislador. O Brasil está atrás de outras grandes nações com respeito à regulamentação da publicidade, especialmente a infantil, e como fez ao inovar com o Código de Defesa do Consumidor e Estatuto da Criança e Adolescente, diplomas de renome internacional e frequentemente estudados e citados em outros países como referência, deveria ser mais uma vez exemplo, inspirando-se em poucos países que oferecem uma regulamentação apropriada para o público infantil, como Alemanha e Inglaterra.

\section{REFERÊNCIAS}

ALEXY, Robert. Teoria dos direitos fundamentais. Trad. Virgílio Afonso da Silva. São Paulo: Malheiros, 2008.

ALMEIDA, Candido Eduardo Mendes de. A autorregulamentação publicitária no Brasil. Rio de Janeiro: Pontifícia Universidade Católica do Rio de Janeiro, 2013. 
ALVAREZ, Ana Maria Blanco Montiel; PASQUALOTTO, Adalberto. (Org.) Publicidade e proteção da infância. Porto Alegre: Livraria do Advogado, 2014.

ARAGÃO NETO, Dário. Direitos humanos e a publicidade infantil na Argentina e no Brasil. Disponível em: <http://coral.ufsm.br/congressodireito/anais/2013/6-12.pdf>. Acesso em: 23. Jul. 2015.

ARANHA, Maria Lúcia de Arruda; MARTINS, Maria Helena Pires. Filosofando. 3. ed. São Paulo: Moderna, 2003.

BASTOS, Celso Ribeiro. Os limites à liberdade de expressão na Constituição da República. Cadernos de direito constitucional e ciência política, São Paulo, n. 20, jul./set. 2007.

BENJAMIN, Antonio Herman de Vasconcellos. [et al.] Código brasileiro de defesa do consumidor: comentado pelos autores do anteprojeto. Rio de Janeiro: Forense, 2001.

BESSA, Ana Cláudia. Principais consequências da publicidade infantil.

Disponível

em:

$<$ http://futurodopresente.com.br/ana/2010/06/principaisconsequencias-da-publicidade-infa ntil>. Acesso em: 31. Maio. 2015.

BRASIL. Conselho Nacional de Autorregulamentação Publicitária. História. Disponível em: <www.conar.org.br>. Acesso em: 31. Maio. 2015.

- Conselho Nacional dos Direitos da Criança e do Adolescente. Disponível em: <http://pndh3.com.br/geral/conanda-conselhonacional-dos-direitos-da-crianca-e-do-adoles cente/>. Acesso em 10. Jul. 2015.

- Secretaria de Direitos Humanos. Conselho Nacional dos Direitos da Criança e do Adolescente (Conanda). Disponível em: <http://www.sdh.gov.br/sobre/participacao-social/conselhonacional-dos-direitos-da-crianca-e-do-adolescente-conanda>.

Acesso em 10. Jul. 2015.

- Tribunal de Justiça do Estado de São Paulo. Agravo de instrumento n. ${ }^{\circ}$ 2062129-22.2014.8.26.0000, Relator Fabio Tabosa. Data de Julgamento: 07/07/2014. 2. ${ }^{\text {a }}$ Câmara Reservada de Direito Empresarial. Data de Publicação: 08/07/2014. Disponível em: <http://tj-sp.jusbrasil.com.br/jurisprudencia/126688461/agravo-deinstrumento-ai-2062 129 2220148260000-sp-20621292220148260000>. Acesso em: 05. Jun. 2015. 
. Tribunal de Justiça do Estado de São Paulo. Apelação n. ${ }^{\circ}$ 001823417.2013.8.26.0053. Relator Fermino Magnani Filho. Data de Julgamento: 29/06/2015. 5. ${ }^{a}$ Câmara de Direito Público. Data de Publicação: 30/06/2015. Disponível em: <http://tjsp.jusbrasil.com.br/jurisprudencia/204200291/apelacao-apl-182341 720138260053-sp-0018234-1720138260053 >. Acesso em: 15. Jul. 2015.

BRITTO, Igor Rodrigues. Infância e publicidade: proteção dos direitos fundamentais da criança na sociedade de consumo. 1. ed. Curitiba: CRV, 2010.

CAMPELLO, Rachel. No mundo da publicidade infantil. Organização ABAP. Disponível em: <http://www.abapnacional.com.br/pdfs/no_mundo_da_publicidade _infantil.pdf>. Acesso em: 23. Jul. 2015.

CANOTILHO, José Joaquim Gomes. Direito constitucional e teoria da constituição. 8. ed. São Paulo: Almedina Brasil, 2004.

COELHO, Fábio Ulhoa. O empresário e os direitos do consumidor. São Paulo: Saraiva, 1994.

CONSUMO E INFÂNCIA. Chile aprova lei que proíbe publicidade de alimentos não saudáveis para menores de 14 anos. Disponível em: <http://www.consumi smoeinfancia.com/15/05/2012/chileaprova-lei-que-proibe-publicidade-de-alimentos-nao-saudaveis para-menores-de-14-anos/>. Acesso em: 23. Jul. 2015.

DIAS, Lúcia Ancona Lopez de Magalhães. Publicidade e direito. 2. ed. São Paulo: Revista dos Tribunais, 2013.

DIGIÁCOMO, Murillo José; DIGIÁCOMO, Ildeara Amorim. Estatuto da criança e do adolescente anotado e interpretado. 6. ed. Curitiba: Ministério Público do Estado do Paraná - Centro de Apoio Operacional das Promotorias da Criança e do Adolescente, 2013.

FROTA, Mário. A publicidade infanto-juvenil: perversões e perspectivas. Curitiba: Juruá, 2006.

FUTURO DO PRESENTE. Fim do abuso da \#publicidade infantil! Disponível em: <http://futurodopresente.com.br/blog/index.php/tag/resolucao163/>. Acesso em: 10. Maio. 2015.

GUSMÃO, Ronaldo. O insustentável consumo norte americano. Disponível

em: 
<http://www.techoje.com.br/site/techoje/categoria/detalhe_artigo/1 1>. Acesso em: 21. Jul. 2015.

HENRIQUES, Isabella. Publicidade de alimentos e crianças: a regulamentação no Brasil e no mundo. São Paulo: Saraiva, 2013.

INSTITUTO ALANA. Criança e Consumo. Disponível em: $<$ http://criancaeconsumo.org.br/ internacional/inglaterra/>. Acesso em: 16. Jul. 2015.

LIMA, Miguel M. Alves. O direito da criança e do adolescente: fundamentos para uma abordagem principiológica. Tese (Doutorado em Direito) - Curso de Pós-Graduação em Direito, Universidade Federal de Santa Catarina, Florianópolis, 2001.

MENDES, Gilmar Ferreira; BRANCO, Paulo Gustavo Gonet. Curso de direito constitucional. 7. ed. São Paulo: Saraiva, 2012.

Migalhas On line. Instituto Alana denúncia publicidade abusivas para crianças. Disponível em: <www.migalhas.com.br/Quentes/17,MI218698,31047-

Instituto+Alana+denuncia $+\mathrm{p}$ ublicidades +abusivas+ para +crianças>. Acesso em: 08. Maio. 2015.

ONG Criança e Consumo. Entenda a resolução que define a abusividade da publicidade infantil. Disponível em: $<$ http://criancaeconsumo.org.br/noticias/entenda-a-resolucao-quedefine-a-abusividade-da-publicidade-infantil/>. Acesso em 10. Jul. 2015.

PEREIRA JÚNIOR, Antonio Jorge. Direitos da criança e do adolescente em face da TV. São Paulo: Saraiva, 2011.

PORTO, Renato. Publicidade digital: proteção da criança e do adolescente. São Paulo: Saraiva, 2014.

PORTUGAL. Código Da Publicidade. Decreto-Lei n. ${ }^{\circ}$ 330/90 de 23 de Outubro. Disponível em: <http://www.bocc.ubi.pt/pag/estadoportugues-codigo-publicidade.html>. Acesso em: 15. Jul. 2015.

POTIGUAR, Alex. Liberdade de expressão e o discurso do ódio: a luta pelo reconhecimento da igualdade como direito à diferença. Brasília: Consulex, 2012.

Ranking IDH Global 2013. Disponível em: <http://www.pnud.org.br/atlas/ranking/Ranking-IDH-Global2013.aspx>. Acesso em: 23. Jul. 2015.

ROBERTI JUNIOR, João Paulo. Evolução jurídica do direito da criança e do adolescente no Brasil. Revista da Unifebe (online). 2012. 
SANTOS, Andréia Mendes dos. Uma relação que dá peso: propaganda de alimentos direcionada para crianças, uma questão de saúde, direitos e educação. Publicidade e Proteção da Infância. Porto Alegre: Livraria do Advogado, 2014.

SILVA, Alexandre Assunção e. Liberdade de expressão e crimes de opinião. São Paulo: Atlas, 2012.

SILVA, Julia Lenzi; ORMELESI, Vinicius Fernandes. Apostila de direitos humanos: 1. ${ }^{\circ}$ Curso Concentrado de Direitos Humanos, Franca, 2015.

SILVA, Rosane Leal da; MARQUEZAN, Bibiana Simões. A publicidade online: desafios para proteger crianças $e$ adolescentes da publicidade abusiva na Internet. Disponível em: $<$ http://www.ambitojuridico.com.br/site/index.php?n_link=revista_a rtigos_leitura\&artigo_i d=9675>. Acesso em: 23. Jul. 2015.

SPERANZA, Henrique de Campos Gurgel. Publicidade enganosa e abusiva. <http://www.ambitojuridico.com.br/site/?n_link=revista_artigos_le itura\&artigo_id=11909>. Acesso em: 06. Abr. 2015. 